\title{
Fugitive Emissions of Volatile Organic Compounds from a Tailings Pond in the Oil Sands Region of Alberta
}

Samar G. Moussa ${ }^{1 *}$, Ralf M. Staebler ${ }^{1}$, Yuan You ${ }^{l}$, Amy Leithead ${ }^{l}$, , Meguel A. Yousif ${ }^{l}$, Peter Brickell $^{1}$, James Beck ${ }^{2}$, Zhimei Jiang ${ }^{1}$, John Liggiol, Shao-Meng Lil ${ }^{1,3}$, Sumi N. Wren ${ }^{l}$, Jeffrey R. Brook, ${ }^{1,4}$ Andrea Darlington ${ }^{1}$, Stewart G. Cober ${ }^{1}$

${ }^{1}$ Air Quality Processes Research Section, Air Quality Research Division, Environment and Climate Change Canada, 4905 Dufferin St., Toronto, ON, M3H 5T4

${ }^{2}$ Suncor Energy Inc., Calgary, Alberta, T2P 3 Y7

${ }^{3}$ College of Environmental Science and Engineering, Peking University, Beijing 100871, China

${ }^{4}$ Dalla Lana School of Public Health and Department of Chemical Engineering and Applied Chemistry, University of Toronto, 223 College St., Toronto, Ontario, M5T 1R4

*Authors to whom correspondence should be addressed: samar.moussa@ec.gc.ca; phone (416) 739-4942; and ralf.staebler@ec.gc.ca; phone (416) -739-5730; FAX (416) 739-4281

Supporting Information

Environmental Science and Technology 


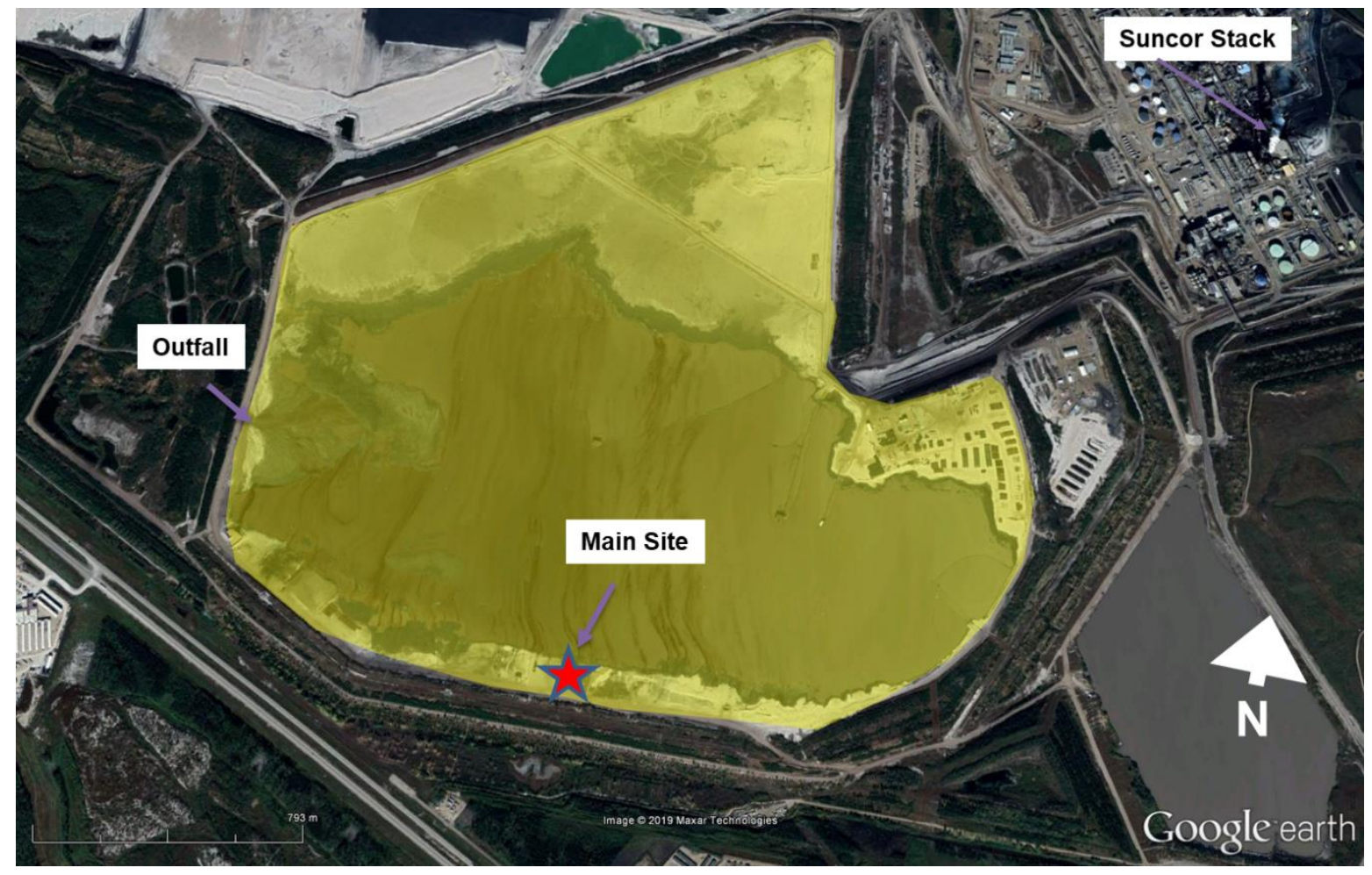

Figure S1: Google Earth image of Suncor Pond 2/3 (dated September 15 ${ }^{\text {th }}, 2017$ ) showing the location of the main site on the south shore of the pond, the location of the fresh outfall and the Suncor facility main stack. The pond area has been artificially shaded yellow.

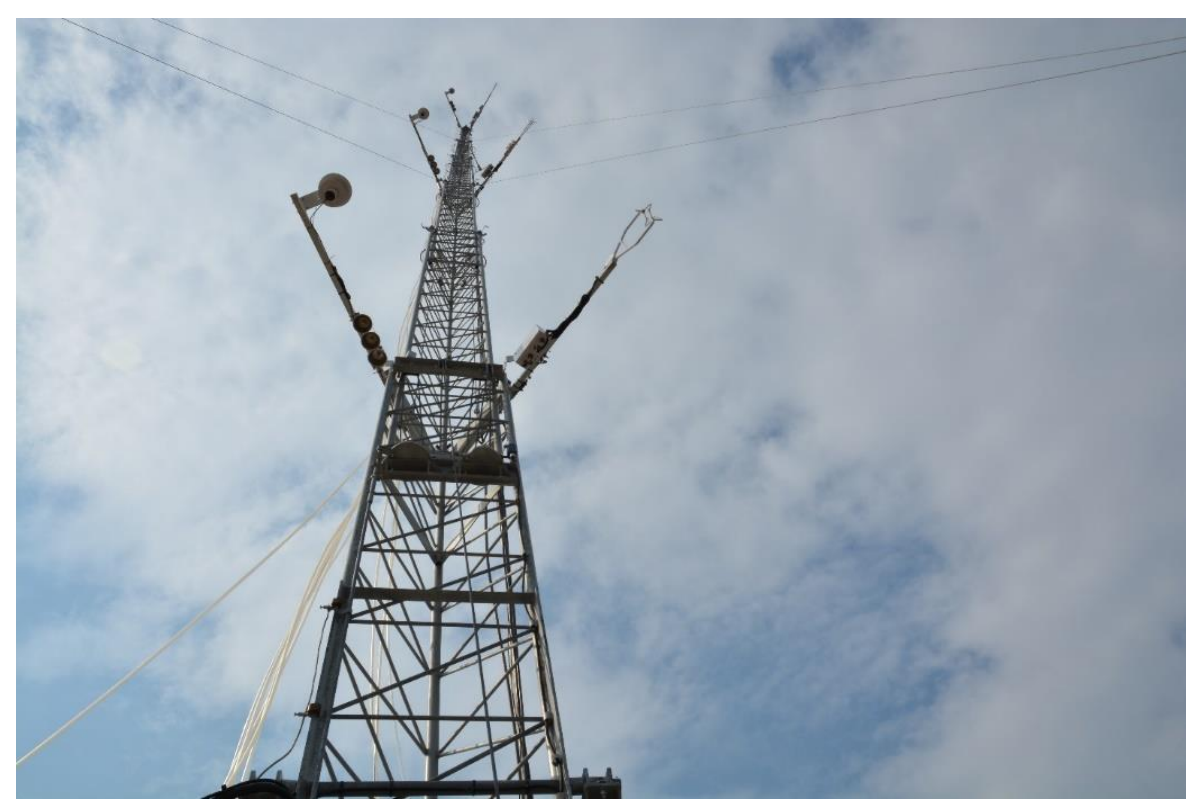

Figure S2: The $32 \mathrm{~m}$ tower from the bottom. The $8 \mathrm{~m}, 18 \mathrm{~m}$ and $32 \mathrm{~m}$ sonic anemometers are to the right, the temperature/humidity probes and gas inlets are to the left. 


\section{S1 Gas Profile Level Switching}

Air was sampled through $1.27 \mathrm{~cm}$ (O.D.) Teflon tubing at four different levels:
a. $\quad 32 \mathrm{~m}$
b. $\quad 18 \mathrm{~m}$
c. $\quad 8 \mathrm{~m}$
d. $\quad 4 \mathrm{~m}$

Inlets for the upper three were located on the mobile tower (Figure S2), and line lengths for these three levels were identical $(40 \mathrm{~m})$ from the open inlet to the switching box on the roof of the trailer. A fourth inlet with shorter length tubing $(1.5 \mathrm{~m})$ was located on the top of the instrument trailer at a height of $4 \mathrm{~m}$ above ground. Each level was connected to a solenoid valve inside the switching box. The sampling sequence was from bottom (level 1) to top (level 4), followed by level 1.

\section{S2 Methods}

S2.1 PTR-TOF-MS: The PTR-ToF-MS measurements began on July $31^{\text {st }}$ and continued until September $5^{\text {th }}, 2017$ with a $10 \mathrm{~s}$ time resolution. The sample flow was $4 \mathrm{~L} \mathrm{~min}^{-1}$ from the main sampling line and $1 \mathrm{~L} \mathrm{~min}^{-1}$ through a catalytic converter for baseline subtractions. The catalytic converter removed VOCs from the sample stream by catalytic thermal oxidation at $350{ }^{\circ} \mathrm{C}$. Zero air from the catalytic converter was sampled for 5 minutes every hour.

Data was processed using the TOFWARE software (Tofwerk AG), which fit individual mass spectral peaks and normalized the peak areas by the reagent ion peak $\left(\mathrm{H}_{3} \mathrm{O}^{+}\right)$. Calibrations for 18 compounds were conducted during and after the study using standard gas cylinders (Apel-Riemer, Scott-Marrin, Inc., and Ionicon Analytik) with the resulting calibration factors applied to the data. The mass resolution of the PTR-ToF-MS ( 4000) is sufficient to provide an elemental composition of many compounds but is unable to separate isomers. Therefore, the concentration data are reported as an elemental formula (where required) but represent the sum of all structural isomers. For compounds without a gas standard, relative response factors and rate constants were calculated using the transmission efficiency and other parameters of the instrument, along with the molecular weight and chemical structure of each compound in a method described by Sekimoto et al, $2017 .{ }^{1}$ 
S2.2 Whole Air Samples: During the study, a total of 13 instantaneous ambient whole air samples were collected at the site. After cryogenic pre-concentration, the samples were analyzed on a gas chromatograph (GC) (Agilent Technologies, 5890 Series II) equipped with two flame ionization detectors (FID). Water or carbon dioxide removal from the sample air stream was not required due to instrumentation design. Analyte peak areas were calibrated using a primary standard gas mixture (National Physical Laboratory, UK) containing the majority of the compounds reported, with mixing ratios (ca. 4 ppbv) of comparable magnitude to the sample air. In addition to absolute instrument calibration, a reference air sample of known composition was analyzed daily to verify instrument performance and stability. Sample air was drawn from the canisters through a preconcentration system by means of a vacuum created in a measured volume. The difference in volume pressure before and after sample trapping was used to calculate the actual sample air volume that was being analyzed. The pre-concentration system was made up of a cryogenic trap consisting of $15 \mathrm{~cm}$ of $3 \mathrm{~mm}$ O.D. silica-lined stainless steel tubing filled with approximately 850 mg of 80/100 mesh silanized glass beads, retained by silanized glass wool plugs. The trap was cooled to $-185^{\circ} \mathrm{C}$ with liquid nitrogen under PID temperature control. The cryogenic trap pressure was maintained below 400 torr at all times to avoid liquefaction of air and the concurrent loss of some species. After the sample, analysis was completed, a $300 \mathrm{~mL}$ volume of ultra-pure helium gas (BIP grade, Air Products) was passed through the system to flush any remaining sample air from the lines and into the trap. Subsequently the cryogenic trap was isolated from the sampling line and resistively heated to $125^{\circ} \mathrm{C}$. After reaching the final temperature, the trap was switched in line with the GC/FID carrier gas stream which injected the trapped hydrocarbons onto the head of the analytical column.

Analytical separation was performed by a variant of 2-dimensional GC whereby the analytes were initially roughly separated by boiling point on a pre-column $(45 \mathrm{~m}, \mathrm{SPB}-1,0.53 \mathrm{~mm} \mathrm{ID,} 5 \mu \mathrm{m}$ film, Supelco). Low boiling point species $\left(\mathrm{C}_{2}\right.$ and $\left.\mathrm{C}_{3}\right)$ were directed onto, and separated by, a pair of GS-Q columns in series (30 m X $0.53 \mathrm{~mm}$ ID each, J\&W Scientific) and quantified by a flame ionization detector (FID). Higher boiling point compounds $\left(\mathrm{C}_{4}\right.$ to $\left.\mathrm{C}_{9}\right)$ were separated by an Aluminum Oxide/KCl column (30 m X $0.53 \mathrm{~mm}$ ID, Restek) and quantified with a second FID. The GC oven temperature program started at $35{ }^{\circ} \mathrm{C}$ and increased to $190{ }^{\circ} \mathrm{C}$ with several ramp steps and hold times incorporated. Individual compound peak areas from the FIDs were calibrated by application of response factors derived from analysis of the primary standard gas. 


\section{S2.3 HCHO and C2H6 measurements:}

The QCL measures these two species based upon their absorption of light from a laser source emitting 1765 and $2990 \mathrm{~cm}^{-1}$ for $\mathrm{HCHO}$ and $\mathrm{C}_{2} \mathrm{H}_{6}$, respectively. Concentrations were derived by applying a nonlinear least squares fitting algorithm to fit the absorption at the defined wavelength, and utilizing an effective path length of $204 \mathrm{~m}$. Samples from the three levels were collected at a frequency of $1 \mathrm{~Hz}$, through $0.635 \mathrm{~cm}$ (O.D.) PFA tubing, with a flow restricted by a critical orifice to $\sim 9.8 \mathrm{~L} \mathrm{~min}^{-1}$. The pressure of the instrument was controlled by connecting the outlet to an Alicat pressure controller (PC3P-30PSIA_D) in order to equalize the downstream pressure. Calibrations for ethane and formaldehyde were performed prior to deployment in the field and after the field study.

\section{S2.4 Supporting Measurements:}

Three sonic anemometers (CSAT-3, Campbell Scientific, USA) were used to measure 3-D turbulent wind fluctuations and derive pollutant fluxes through an approach that has been described in detail previously. ${ }^{2}$ The ultrasonic anemometers use three pairs of non-orthogonally oriented transducers to measure the wind in three dimensions. In this application, the wind components and sonic temperature were determined at $10 \mathrm{~Hz}$. From these turbulent wind fluctuations, the momentum flux and sensible heat flux can be calculated and combined with other co-located scalars, to directly calculate eddy covariance fluxes for species measured with fast response instruments (ie: latent heat $\left(\mathrm{H}_{2} \mathrm{O}\right), \mathrm{CO}_{2}$ and $\mathrm{CH}_{4}$ ). The sonic anemometers were located at $8 \mathrm{~m}, 18 \mathrm{~m}$ and $32 \mathrm{~m}$ above ground on the mobile tower.

Temperature and humidity were measured with probes (Model Rotronic HC2-S3-L; radiation shield: Campbell Scientific Model 43502) at every level. Ambient pressure (RM Young Model 61202) was measured at $4 \mathrm{~m}$. An additional wind direction (WD) and speed (WS) measurement was conducted at the $4 \mathrm{~m}$ level using a propeller anemometer (Campbell model 05103-10). All of these aforementioned meteorological parameters were recorded at 1s time resolution.

\section{S3 Ethane Flux during the study}

Figure $3 \mathrm{~A}, \mathrm{~B}$, and $\mathrm{C}$ shows the average 30 minute concentration as a function of height for BTEX, $\mathrm{C}_{5} \mathrm{H}_{8}$, and ethane $\left(\mathrm{C}_{2} \mathrm{H}_{6}\right)$, respectively. Both BTEX and $\mathrm{C}_{5} \mathrm{H}_{8}$ measurements exhibited a clear vertical gradient with maximum concentrations at lower heights, while ethane exhibited a more 
complicated gradient profile with no discernable gradient between the $8 \mathrm{~m}$ and $18 \mathrm{~m}$ levels (Figure S3 C). As shown in Figure S4, this suggests that for ethane, there was no significant source within the footprint of the $18 \mathrm{~m}$ measurement. At $8 \mathrm{~m}$, the pond contributed to the ethane flux. However Figure S3C indicates that there were additional sources within the $32 \mathrm{~m}$ footprint, beyond the pond (e.g.Suncor facility $2 \mathrm{~km}$ east of the sampling site and the pipe yard). Concentration rose and gradient flux plots for ethane (Figure S5) confirm this conclusion and are consistent with a maximum flux of ethane from the direction of the facility ( 45 degrees) and a pipe yard. Ethane is emitted to the atmosphere during extraction, processing, and distribution of processed oil. ${ }^{3} \mathrm{~A}$ small positive flux was also observed at the $195^{\circ}$ wind direction where a diesel generator was stationed to power the instruments in the current study. Thus, VOCs that were found to be correlated with ethane (lower chain alkanes) may also be attributed to these additional sources, and not solely to the tailings pond.

A)

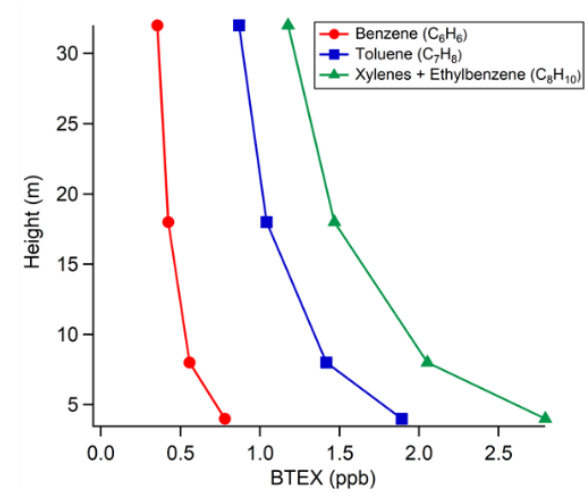

B)

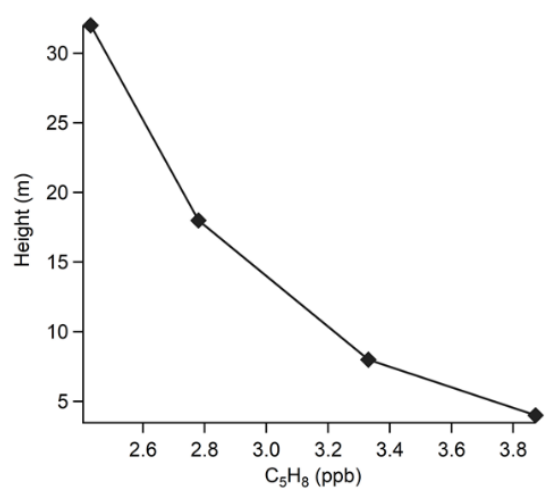

C)

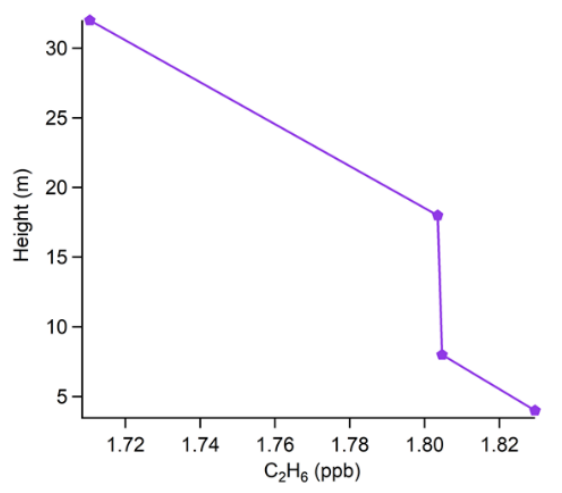

Figure S3: Gradient plots (concentration vs. height) for A) BTEX, B) $\mathrm{C}_{5} \mathrm{H}_{8}$ and C) $\mathrm{C}_{2} \mathrm{H}_{6}$ (Ethane). 

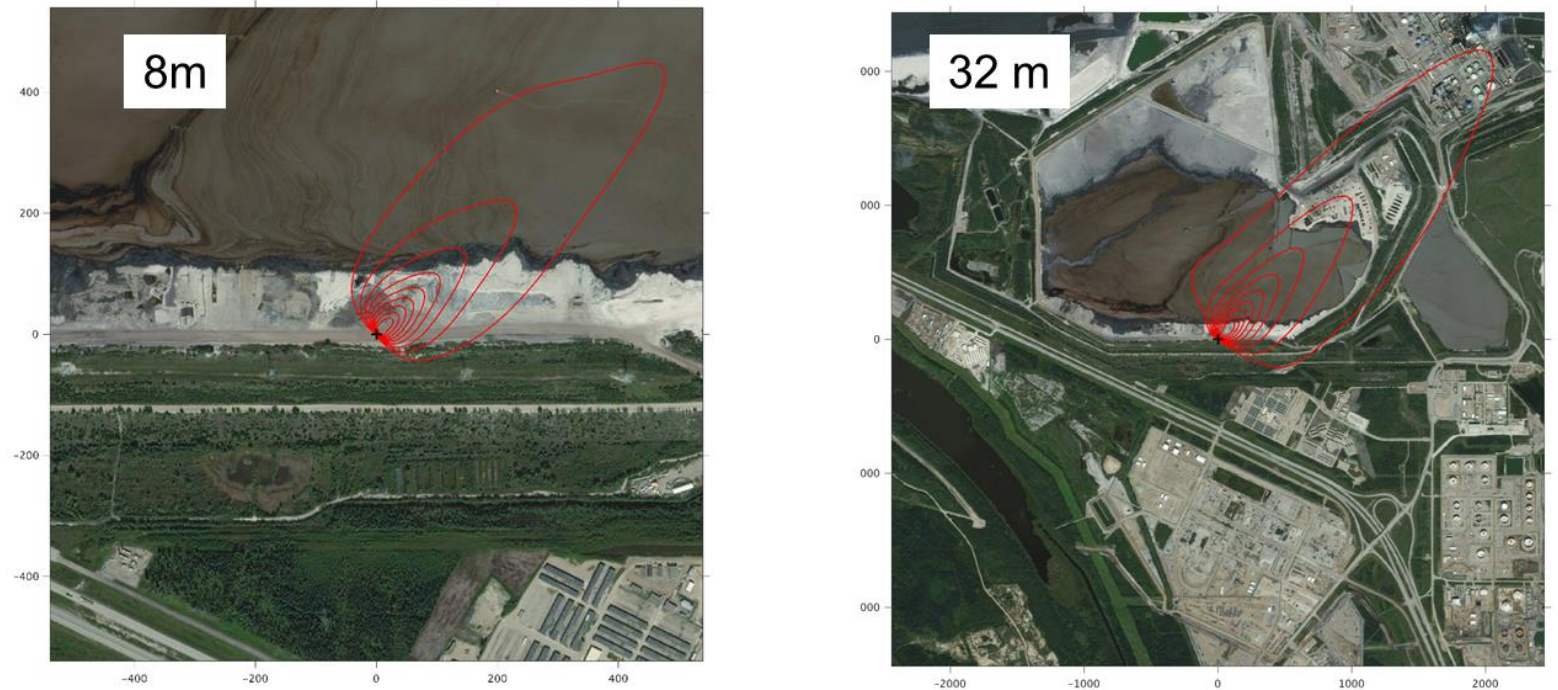

Figure S4: Flux footprints for ethane at $8 \mathrm{~m}$ and $32 \mathrm{~m}$ for the study period when the wind was coming from 45 degrees direction. Footprints calculated using the Flux Footprint Prediction (FFP) algorithm [http://geography.swansea.ac.uk/nkljun/ffp/www/index.php], which bases its algorithm on Kljun et al. (2015). 


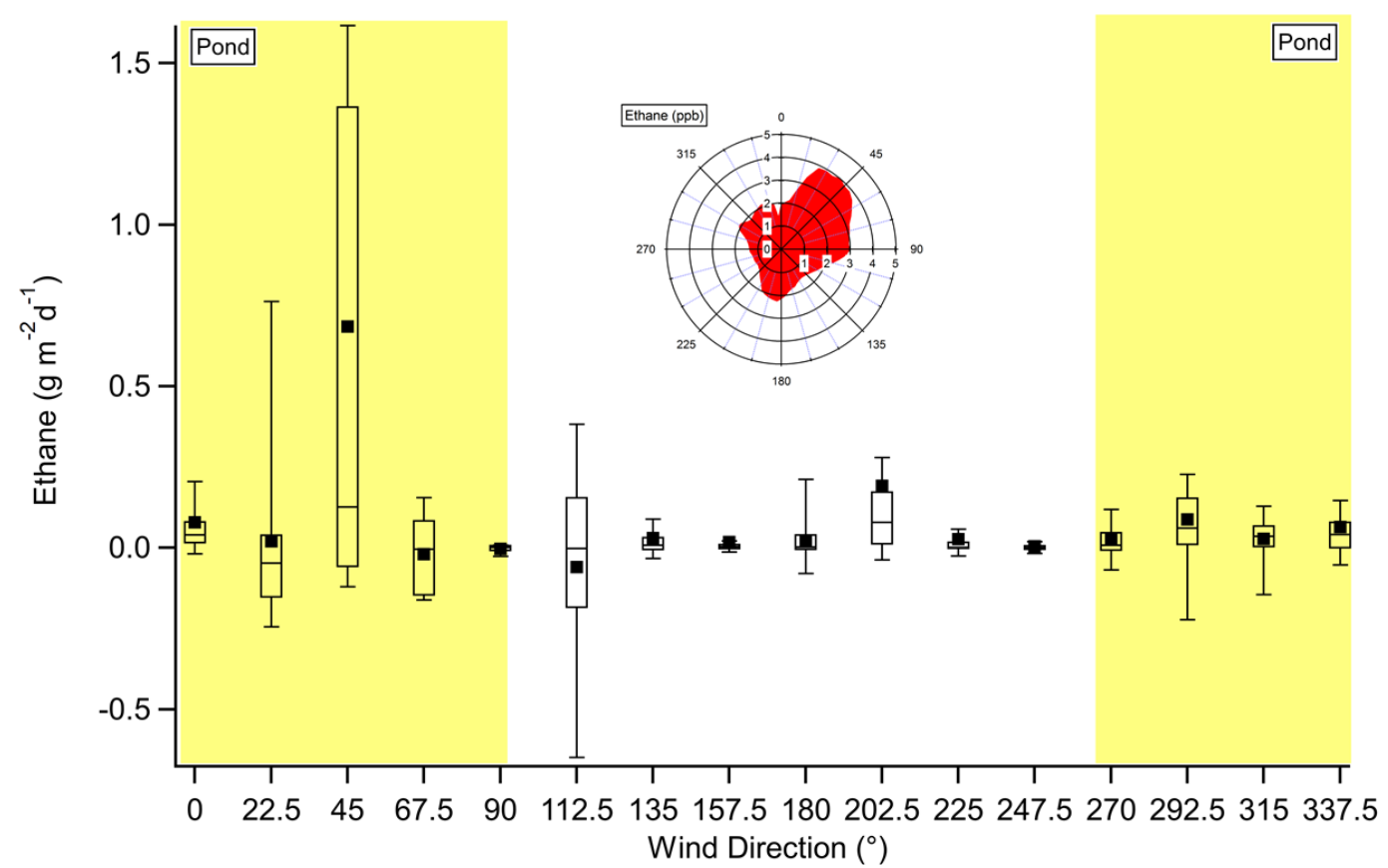

Figure S5: Gradient flux for ethane binned by $22.5^{\circ}$ wind direction increments. The yellow shaded area represent the direction from the pond. The wind rose plot shows ethane concentration (ppb) binned by wind direction.

\section{S4 PTR-ToF-MS derived $\mathrm{C}_{5} \mathrm{H}_{8}$ and $\mathrm{C}_{10} \mathrm{H}_{16}$}

The average isoprene concentration measured by VOC canisters was $0.8 \mathrm{ppb}$ and ranged from 0.06-1.7 ppb; however, the average concentration of $\mathrm{C}_{5} \mathrm{H}_{8}$ from the PTR-ToF-MS was much larger at $3.2 \mathrm{ppb}$ and ranged from $0.4-195.8 \mathrm{ppb}$. Additionally, the poor correlation $\left(\mathrm{R}^{2}=0.1\right)$ of $\mathrm{C}_{5} \mathrm{H}_{8}$ with canister isoprene when the wind was coming from the pond direction, clearly indicates that the pond $\mathrm{C}_{5} \mathrm{H}_{8}$ is not isoprene (Figure S6). In contrast, $\mathrm{C}_{5} \mathrm{H}_{8}$ was well correlated $\left(\mathrm{R}^{2}=0.9\right)$ with canister isoprene for wind directions unaffected by the pond (Fig. S6). The majority of PTR-ToFMS $\mathrm{C}_{5} \mathrm{H}_{8}$ in this study is therefore attributed to cyclopentene and/or the sum of cycloalkane fragments, consistent with other field studies conducted near petroleum and industrial facilities. ${ }^{4-}$ 8 In addition, the MACR+MVK (oxidation products of isoprene) flux show no clear emission from the pond direction (Figure S7), supporting the conclusion that the majority of the detected $\mathrm{C}_{5} \mathrm{H}_{8}$ was not isoprene. Likewise, $\mathrm{C}_{10} \mathrm{H}_{16}$ (detected in the PTR-ToF-MS as $\mathrm{C}_{10} \mathrm{H}_{17}{ }^{+} ; \mathrm{m} / \mathrm{z}$ 137.132), usually interpreted as monoterpenes, exhibited very high fluxes when the wind was coming from the direction of the pond (Figure S8) with minimal contribution from other directions. Given that 
the PTR-ToF-MS does not differentiate between isomers, $\mathrm{C}_{10} \mathrm{H}_{16}$ may be a petroleum product or other non-terpene isomer. ${ }^{4}$ Adamantane (tricyclo[3, 3, 1, 1(3, 7)]decane), a diamondoid found in petroleum products, was suggested by Koss et al. (2017) as a possible non-terpene isomer for $\mathrm{C}_{10} \mathrm{H}_{16}{ }^{4}$ A number of studies showed that adamantane is found in crude oil in concentrations that ranges from $<1$ to $100 \%$ of typical benzene concentrations. ${ }^{4,9,10}$ To lend further support to this argument, diamondoind tricyclic acids such as adamantane carboxylic acids and alkyl-adamantane carboxylic acids have been detected in tailings pond water samples from the OS region as biooxidation products of adamantane and alkyladamantane hydrocarbons. ${ }^{11-15}$ Unfortunately, there were no canister/GC measurements of monoterpenes during this study to directly confirm that the $\mathrm{C}_{10} \mathrm{H}_{16}$ detected was not due to terpenes, but the absence of a strong diurnal cycle of $\mathrm{C}_{10} \mathrm{H}_{16}$ when the wind was from the pond direction (Figure S12) and the strong correlation between $\mathrm{C}_{10} \mathrm{H}_{16}$ and $\mathrm{C}_{11} \mathrm{H}_{18}$ (methyl adamantane which was detected as $\mathrm{C}_{11} \mathrm{H}_{19}{ }^{+}$at $\mathrm{m} / \mathrm{z} 151.148$ ) indicate that this compound was a non-terpene isomer (Figure S13).

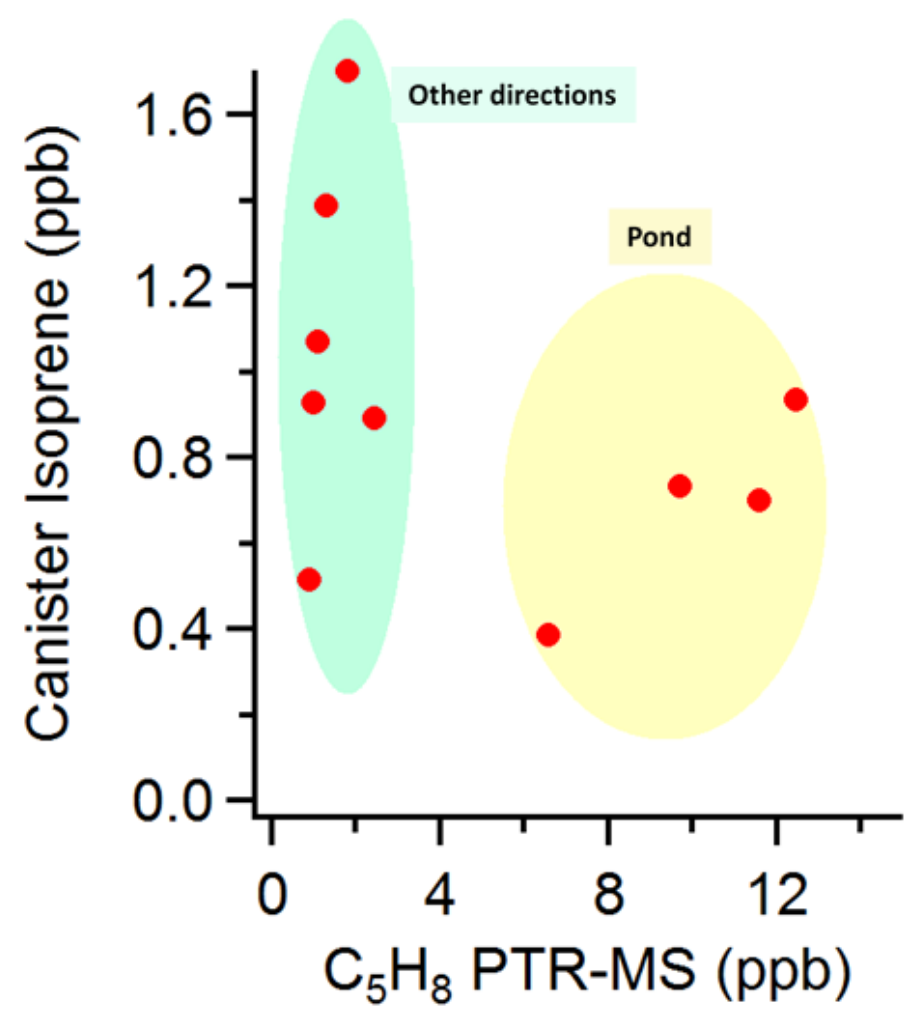

Figure S6: Canister isoprene concentration plotted as a function of $\mathrm{C}_{5} \mathrm{H}_{8}$ concentration from the PTR-ToF-MS. The points for "other directions" approximately lie on a 1:1 line (slope =1.25). 


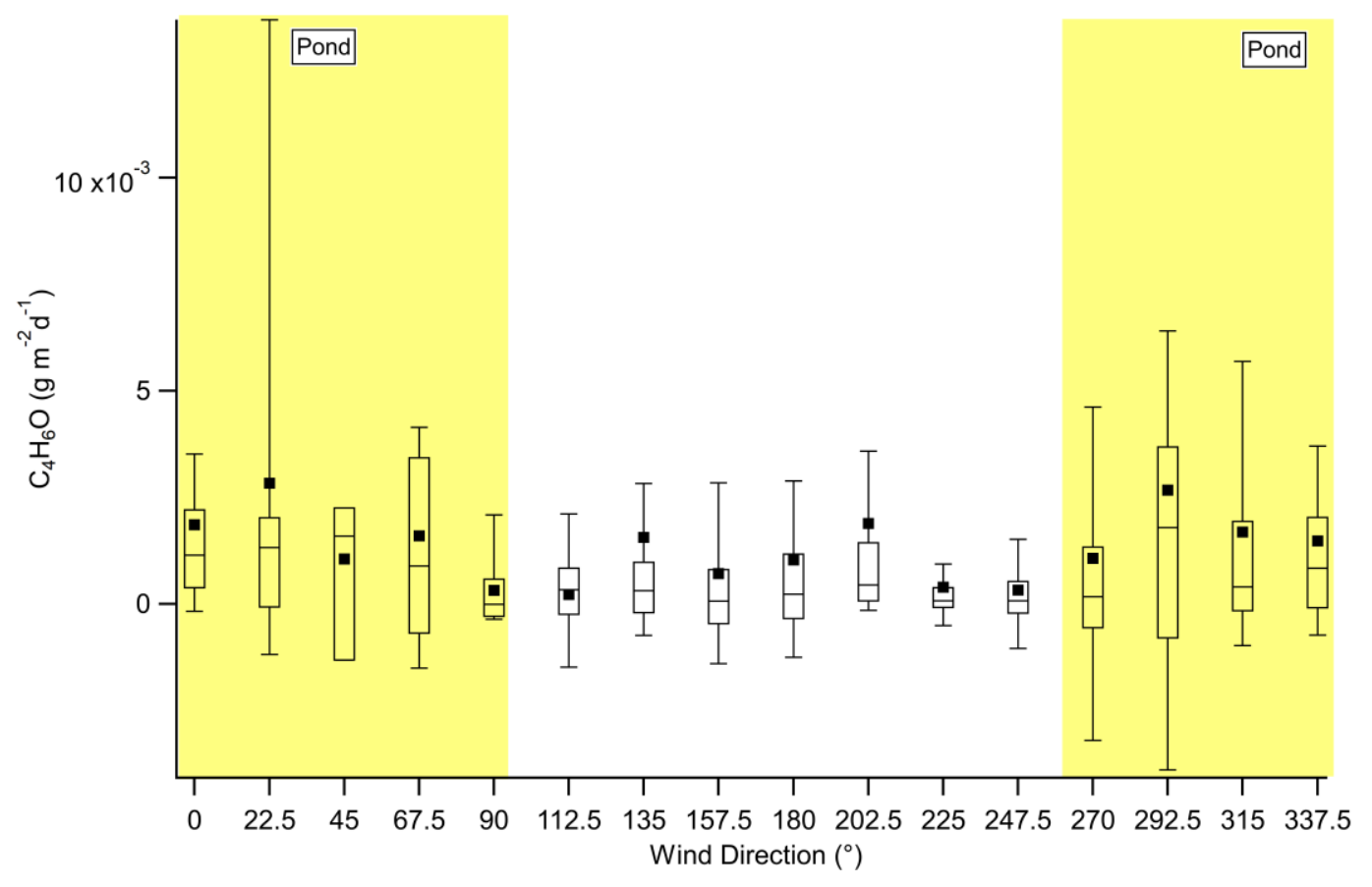

Figure S7: $\mathrm{C}_{4} \mathrm{H}_{6} \mathrm{O}$ (MVK + MACR+ Crotonaldehyde) gradient fluxes as a function of wind direction in 22.5-degree bins. 

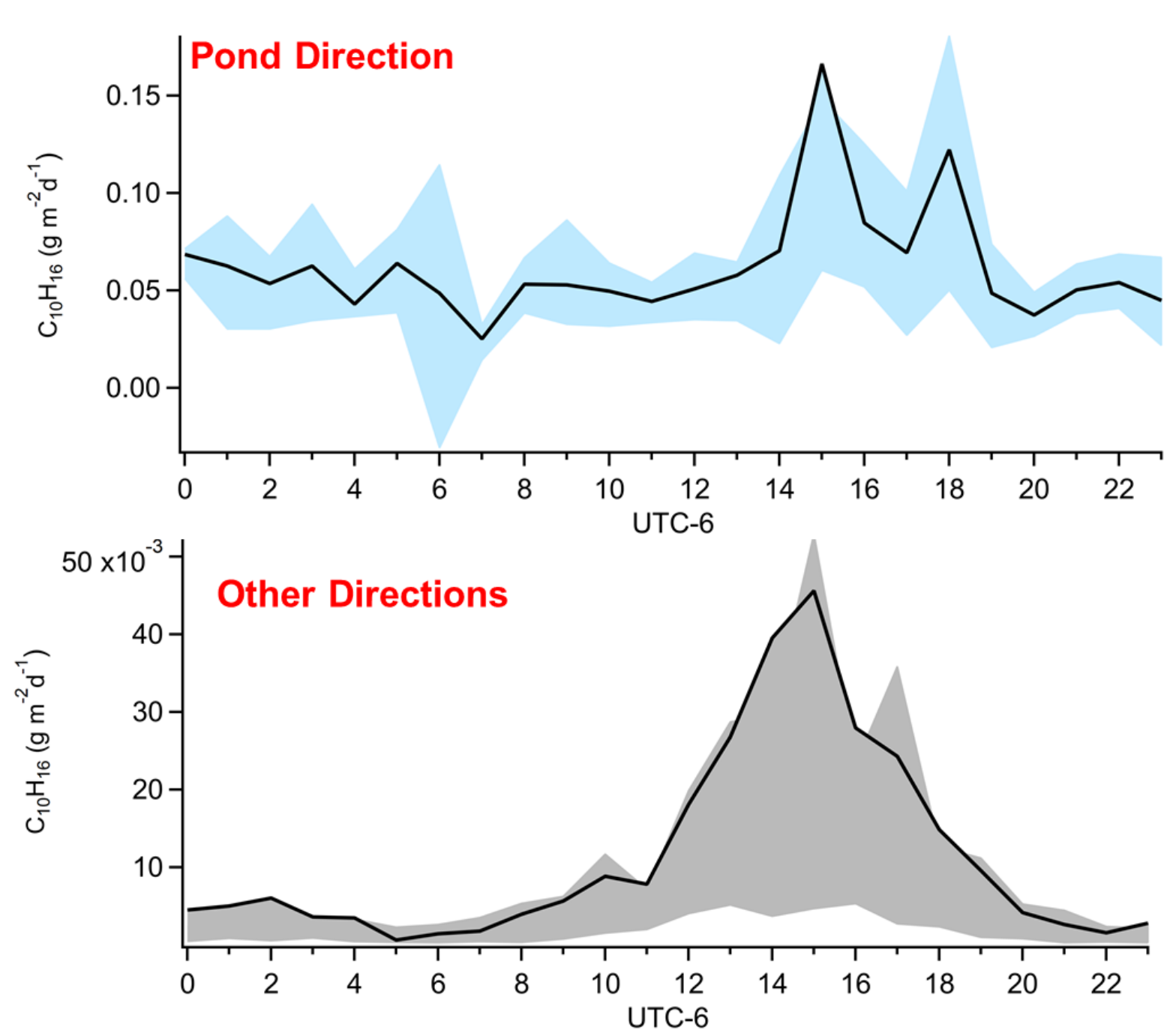

Figure S8: Diurnal cycle plots for $\mathrm{C}_{10} \mathrm{H}_{16}$ flux during the study. The shaded areas represent the $25 \%$ and $75 \%$ quartiles and the solid line is the mean. 


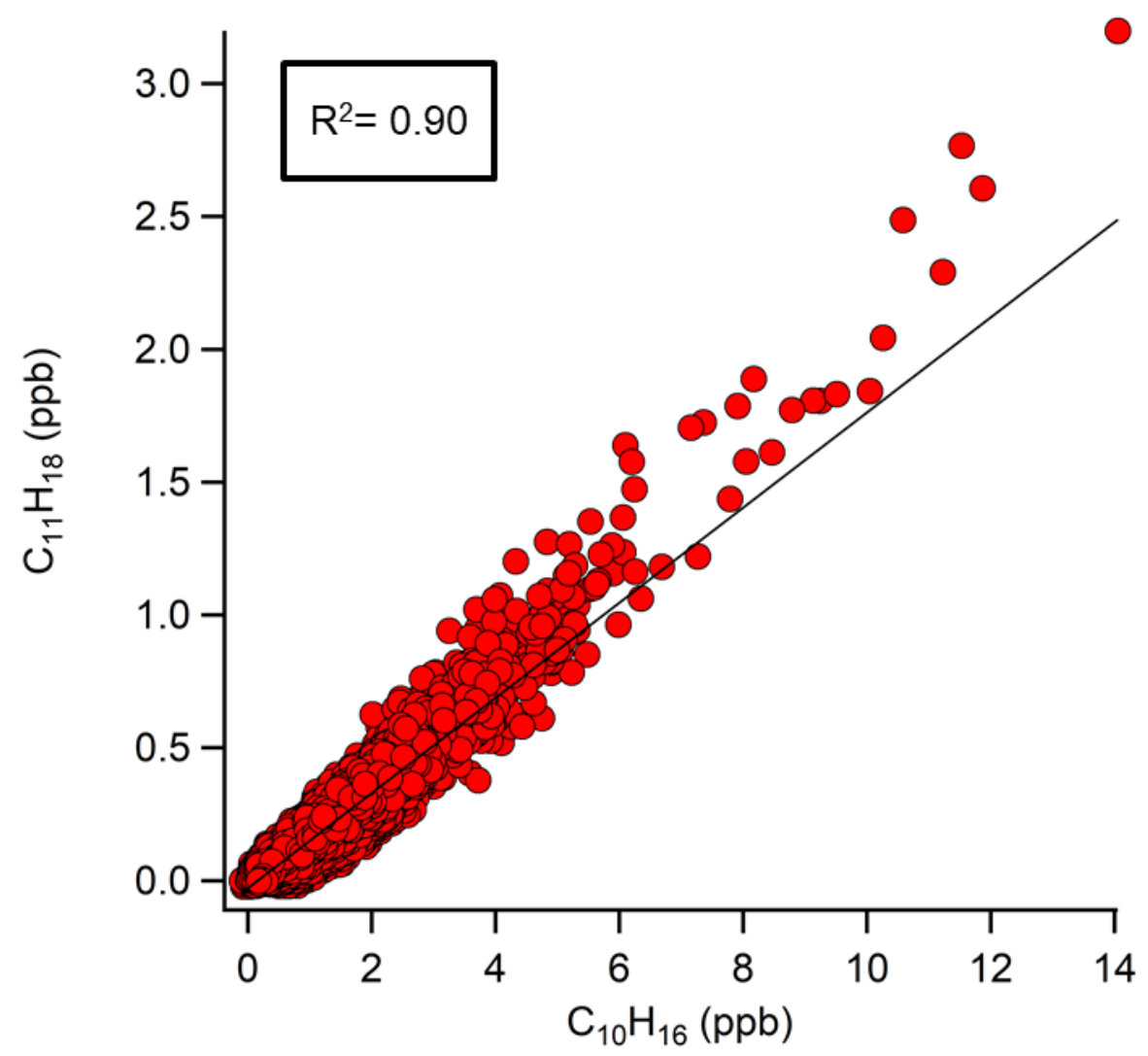

Figure S9: Correlation plot of $\mathrm{C}_{11} \mathrm{H}_{18}$ (methyl adamantane) with $\mathrm{C}_{10} \mathrm{H}_{16}$.

\section{S5 VOC Deriving emissions from Canister Samples}

Correlations between the mixing ratios of the canister VOCs with potential tracers from the PTRToF-MS or the QCL at level 1, were used to derive emissions from the discrete canister samples. In order to ensure that this method was valid, canister $\mathrm{C}_{7} \mathrm{H}_{8}$ (toluene) and $\mathrm{C}_{8} \mathrm{H}_{10}$ (xylenes and ethylbenzene) were correlated with those from the PTR-ToF-MS. As shown in Figure S10, the correlation was strong $\left(\mathrm{R}^{2}>0.99\right)$. The PTR-ToF-MS tracer with the highest correlation coefficient was chosen for each canister VOC. Overall, three PTR-ToF-MS tracers $\left(\mathrm{C}_{8} \mathrm{H}_{10}, \mathrm{C}_{7} \mathrm{H}_{8}\right.$ and $\left.\mathrm{C}_{5} \mathrm{H}_{8}\right)$ and one QCL tracer $\left(\mathrm{C}_{2} \mathrm{H}_{6}\right)$ were used to estimate fluxes for the 22 canister VOCs with correlation coefficients $\left(\mathrm{R}^{2}>0.7\right)$. Figure $\mathrm{S} 11$ shows the correlation plots for several VOCs with the tracers. Most alkanes correlated very well with $\mathrm{C}_{5} \mathrm{H}_{8}$, indicating that the outfall was probably the major source of these species. The rose plot of total alkanes measurements from an open path FTIR instrument during this study (Figure S12) confirms this conclusion. ${ }^{16}$ Shorter chain alkanes $\left(\mathrm{C}_{3^{-}}\right.$ 
$\mathrm{C}_{4}$ ), on the other hand, correlated better with ethane indicating that in addition to the pond, there were other sources contributing to these species.

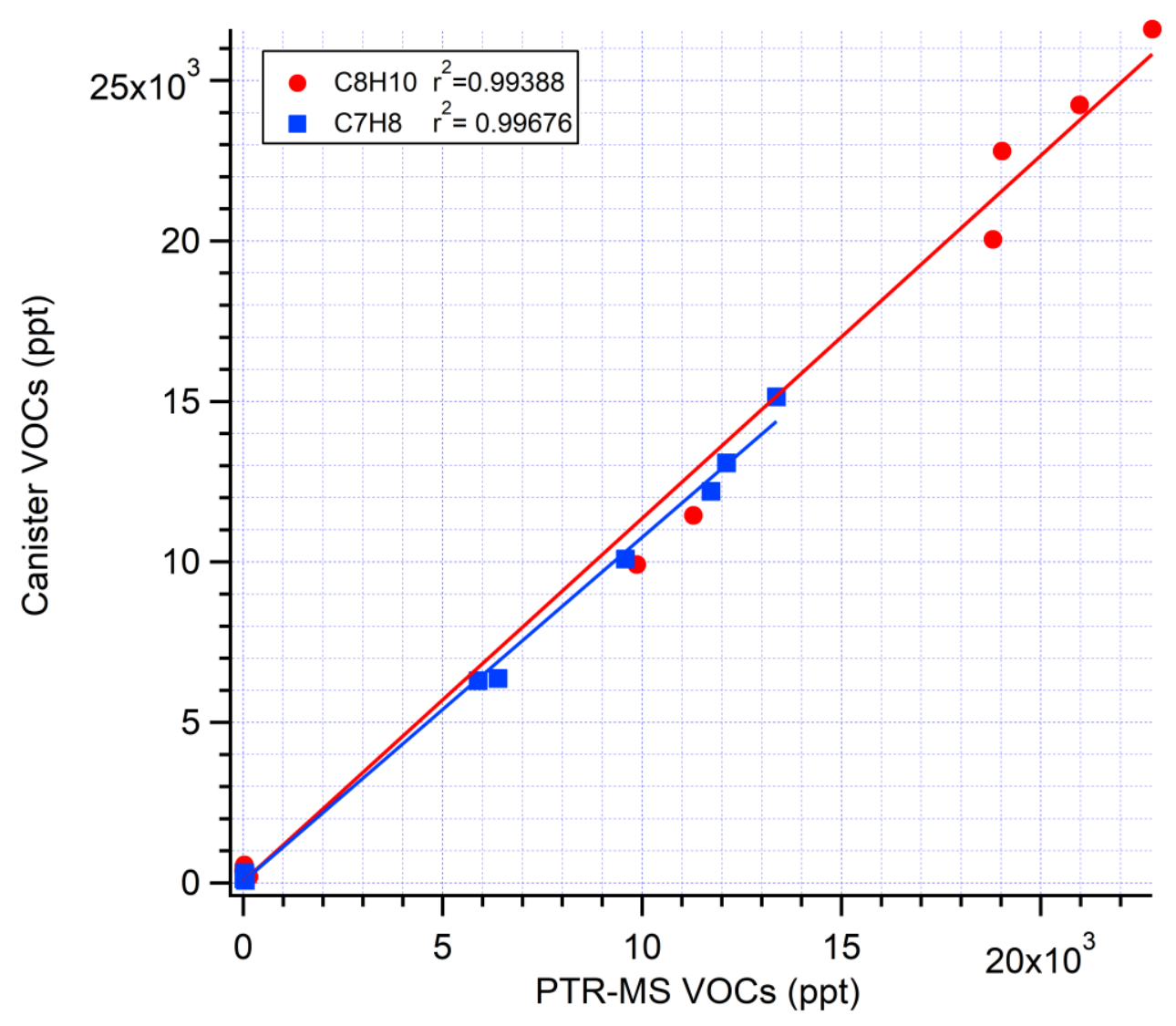

Figure S10: Canister $\mathrm{C}_{7} \mathrm{H}_{8}$ (toluene) and $\mathrm{C}_{8} \mathrm{H}_{10}$ (xylenes and ethylbenzene) correlation with those from the PTR-MS. 

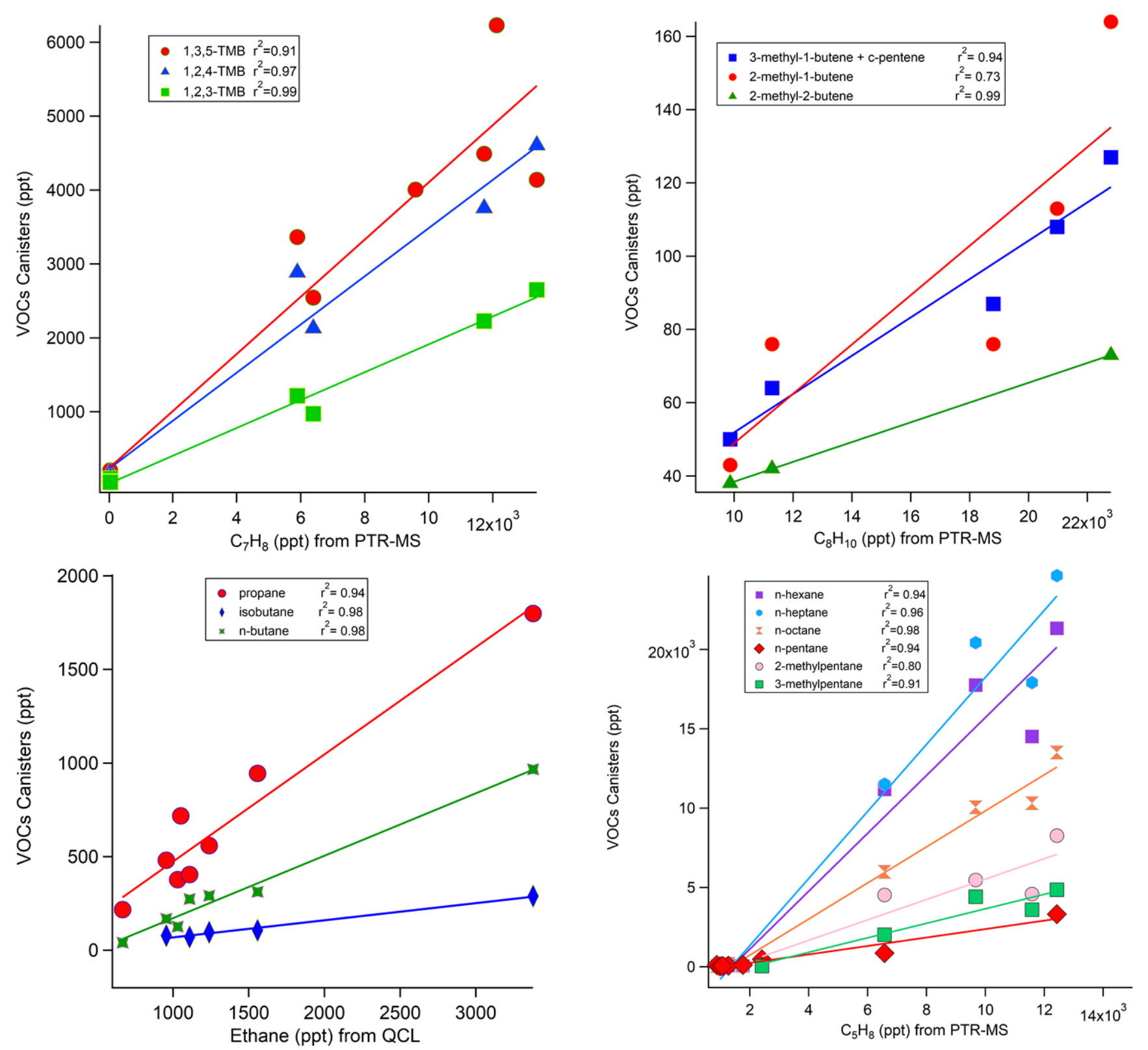

Figure S11: Correlation plots between WAS VOCs and PTR-ToF and QCL tracers. 


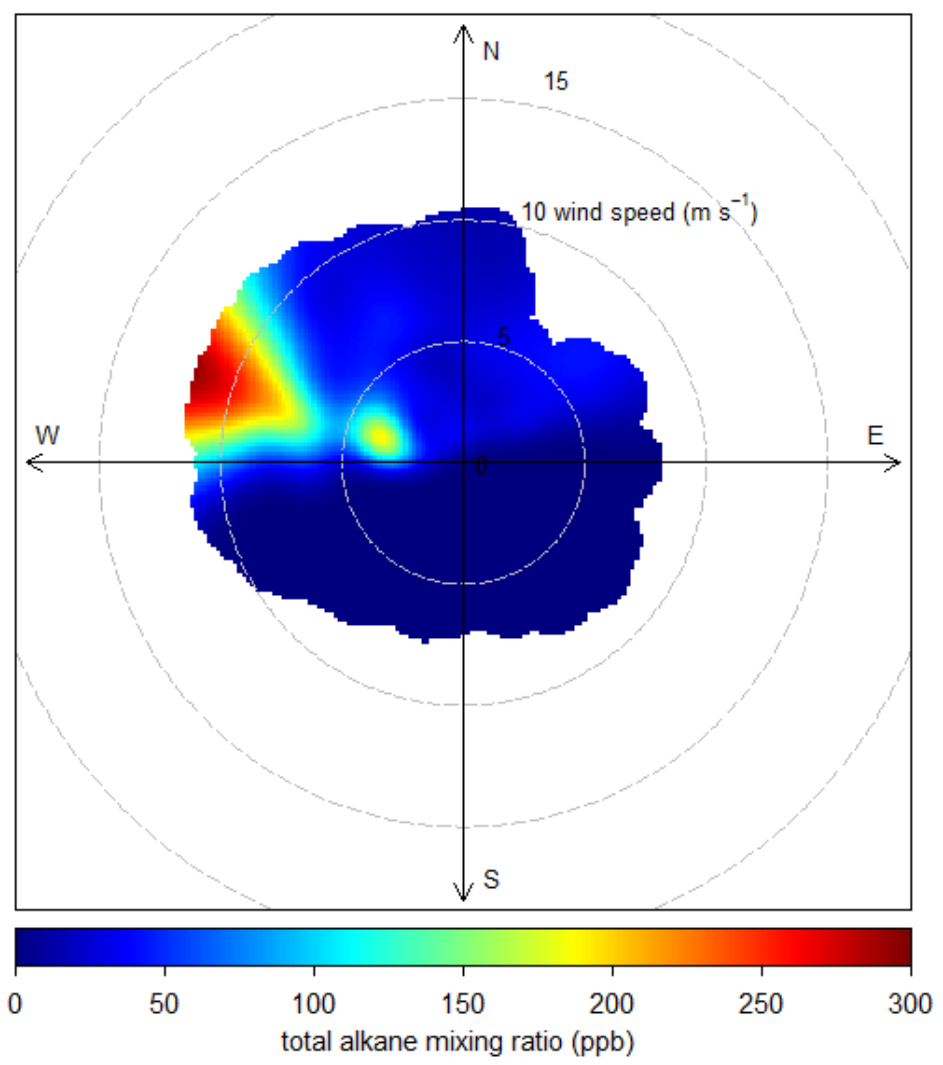

Figure S12: Rose plot for total alkanes measured by an open path FTIR during the study period from Yuan et al. $2020^{16}$. 
A)

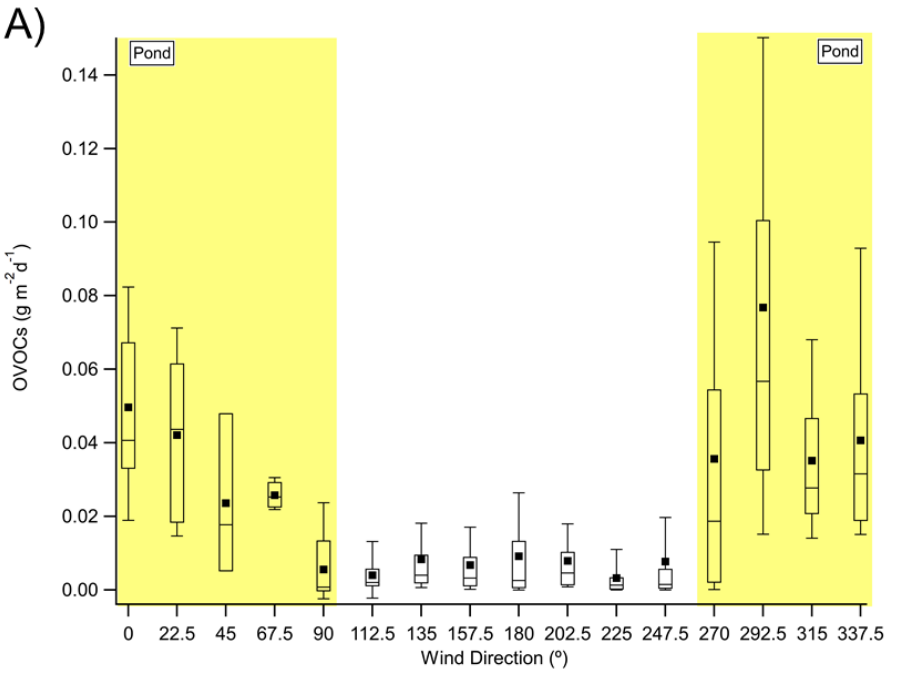

C)

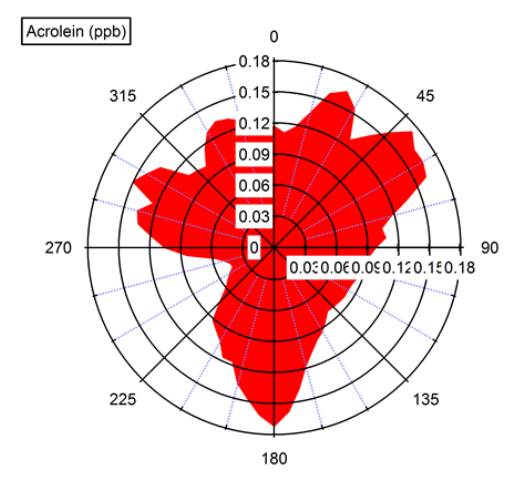

B)
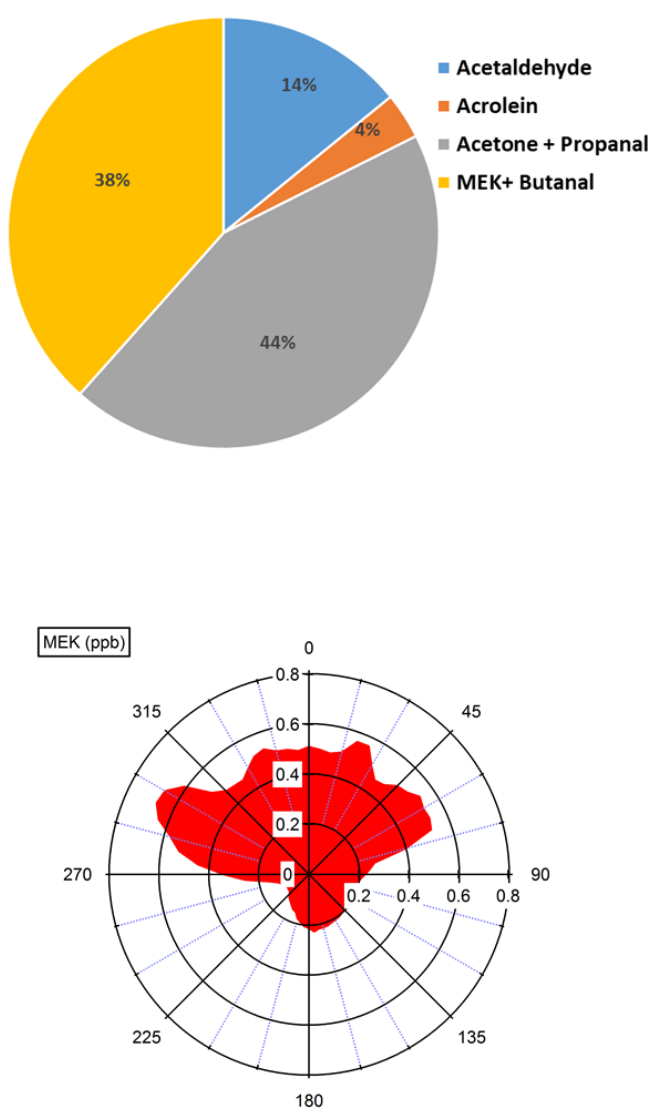

Figure S13: A) OVOCs gradient flux binned by $22.5^{\circ}$ wind direction increments B) OVOCs flux speciation C) Concentration rose plots for acrolein (left) and MEK (right). 


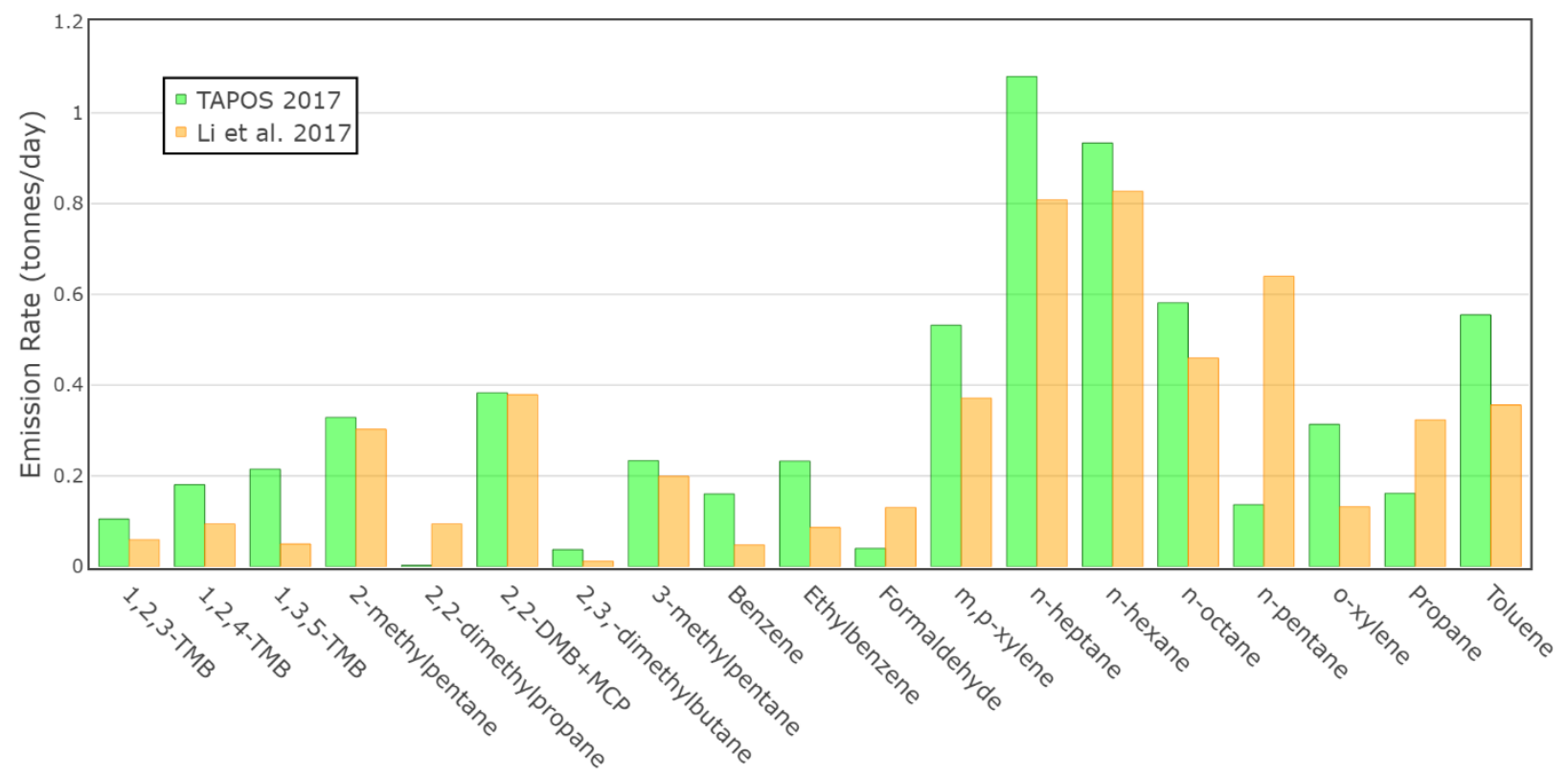

Figure S14: Comparison of speciated VOC emission rates between the current study (TAPOS) and Li et al. (2017) measurements. 


\section{S6 Chemical Mass Balance (CMB)}

\section{S6.1 Overview}

The CMB is a receptor model developed by the Environmental Protection Agency (EPA). It is used to quantify source contributions in observed measurements for air quality management. This model utilizes least squares regression applied to a set of mass-balance equations to attain source contribution estimates (Watson, 2001). ${ }^{17}$ Inputs to the model include source profiles (mass fraction of each chemical compound at each source) and ambient data (receptor concentrations), along with uncertainty estimates. The CMB output is source contributions for each chemical compound with corresponding uncertainty values for each data point that converges to a solution.

\section{S6.1.1 Ambient data and source profiles}

For this study, ambient data was collected in Fort McKay, Alberta (57.18366, -111.63953). Nine volatile organic compounds were measured every $30 \mathrm{~min}$ from July 30, 2017 to September 5, 2017 by a Syntech gas chromatograph (Syntech Spectra GC 955 611) at a ground-based monitoring site in Fort McKay (FMK, Oski-ôtin) as described in Wren et al. (2020): benzene, ethylbenzene, nheptane, n-hexane, 2-methylpentane, n-octane, toluene, o-xylene, and m,p-xylene. ${ }^{18}$ Uncertainties for measurements below the method detection limit (MDL) were assigned as $30 \%$ of the measurement and uncertainties for measurements above the MDL were assigned as their specific relative standard deviation (RSD\%). Table S1 lists the detection limits and RSD\% for each compound. $\mathrm{CMB}$ requires non-zero uncertainty values, therefore measured values of zero were assigned an uncertainty equal to the detection limit in these cases.

Eight sources of these VOCs located near Fort McKay were examined. Li et al., (2017) reported top-down emission rates along with uncertainty values for four OS facilities: Syncrude Mildred Lake (SML), Suncor Millenium (SUN), Canadian Natural Resources Limited Horizon (CNRL), and Shell Albian Jackpine (SAJ) (now owned and operated by CNRL). These top-down emission rates were used to develop facility-specific mass fraction source profiles. ${ }^{19}$

Vehicles emissions from nearby roads and highways are also measured, therefore gas and diesel exhaust profiles obtained from the EPA SPECIATE repository were included. ${ }^{20}$ Profile 8750a (Gasoline Exhaust - Reformulated Gasoline) and 8774 (Diesel Exhaust Emissions from Pre-2007 Model Year Heavy-Duty Diesel Trucks) were used for the gasoline (GAS) and diesel (DSL) emissions, respectively. The SPECIATE profiles were re-normalized to the sum of the VOCs used in the CMB analysis. To develop a background profile for the area, only measurements that met both of the following conditions were used: 1) measurements were made during periods where wind was coming from the west (minimizing local influence); and 2) measurements exhibited low total VOC concentrations ( $<5^{\text {th }}$ percentile). Lastly, a source profile was developed for Pond $2 / 3$ from fluxes calculated in this study (section 3.1). A summary of these source profiles can be seen in Table S2 and Figure S15. 
Many of these sources are distant (>20 km) from Fort McKay, therefore source profiles were adjusted based on $\mathrm{OH}$ reactivity and transit times from the facilities to the site. The transit times were calculated using the wind transport model (described below). Based on the histogram of transit times (Figure S16) the average transit time from the facilities was found to be roughly 3.5 hours for SUN, SML, CNRL and Pond 2/3. Since SAJ is located much closer to Fort McKay, a transit time of 30 minutes was used. The profiles were adjusted assuming $[\mathrm{OH}]=1 \times 10^{6}$ molec $\mathrm{cm}^{-3}$ and using reported first-order rate constants $\left(k_{O H}, \mathrm{~cm}^{3} \mathrm{molec}^{-1} \mathrm{~s}^{-1}\right)$ from Finlayson-Pitts and Pitts. $^{21}$ The reaction-adjusted profiles for all sources are listed in Table S3. All the CMB analysis and discussion used the reaction-adjusted profiles.

Table S1: Compound detection limits and RSD\% for the Syntech instrument.

\begin{tabular}{|l|l|l|l|l|}
\hline Compound & $\begin{array}{l}\text { Molecular } \\
\text { Formula }\end{array}$ & $\begin{array}{l}\text { Detection Limit } \\
(\mathrm{ppbV})\end{array}$ & $\begin{array}{l}\text { Detection } \\
\left(\mu \mathrm{g} / \mathrm{m}^{3}\right)\end{array}$ & 0.035 \\
\hline 2-methylpentane & $\mathrm{C}_{6} \mathrm{H}_{14}$ & 0.01 & 0.035 & 6 \\
\hline n-hexane & $\mathrm{C}_{6} \mathrm{H}_{14}$ & 0.01 & 0.064 & 2 \\
\hline benzene & $\mathrm{C}_{6} \mathrm{H}_{6}$ & 0.02 & 0.082 & 5 \\
\hline n-heptane & $\mathrm{C}_{7} \mathrm{H}_{16}$ & 0.02 & 0.038 & 2 \\
\hline toluene & $\mathrm{C}_{7} \mathrm{H}_{8}$ & 0.01 & 0.093 & 3 \\
\hline n-octane & $\mathrm{C}_{8} \mathrm{H}_{18}$ & 0.02 & 0.043 & 2 \\
\hline ethylbenzene & $\mathrm{C}_{8} \mathrm{H}_{10}$ & 0.01 & 0.043 & 3 \\
\hline m,p-xylene & $\mathrm{C}_{8} \mathrm{H}_{10}$ & 0.01 & 0.043 & 2 \\
\hline o-xylene & $\mathrm{C}_{8} \mathrm{H}_{10}$ & 0.01 & & 2 \\
\hline
\end{tabular}




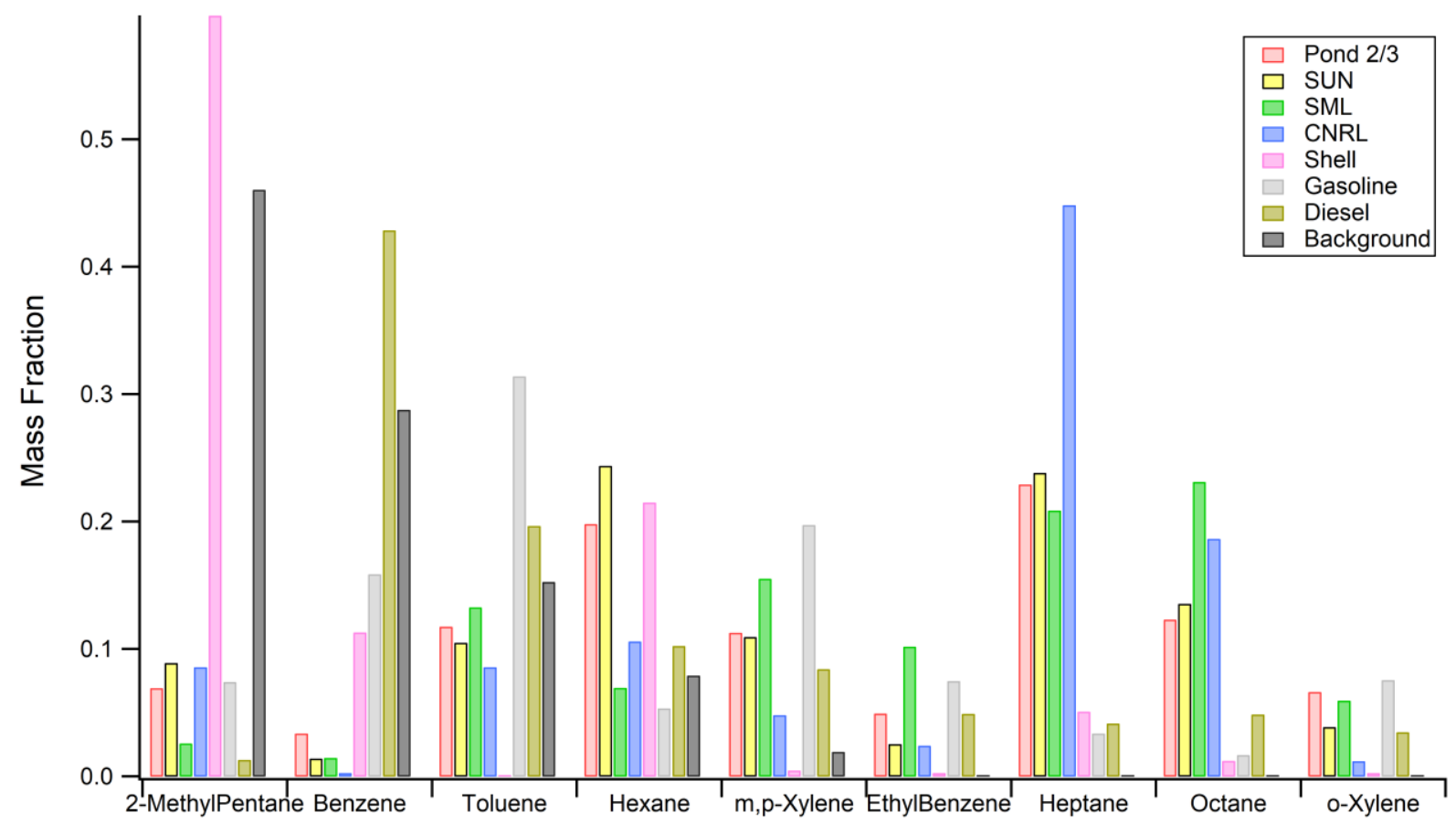

Figure S15: VOC profiles from the different sources used in the CMB analysis. 
Table S2: Original source profiles used in the CMB model.

\begin{tabular}{|c|c|c|c|c|c|c|c|c|c|c|c|c|c|c|c|c|}
\hline \multirow[b]{2}{*}{ VOC } & \multicolumn{2}{|c|}{$\begin{array}{l}\text { Syncrude } \\
\text { (SML) }\end{array}$} & \multicolumn{2}{|c|}{$\begin{array}{l}\text { Suncor } \\
\text { (SUN) }\end{array}$} & \multicolumn{2}{|c|}{ CNRL } & \multicolumn{2}{|c|}{$\begin{array}{l}\text { Shell } \\
\text { (SAJ) }\end{array}$} & \multicolumn{2}{|c|}{ Gasoline } & \multicolumn{2}{|c|}{ Diesel } & \multicolumn{2}{|c|}{ Background } & \multicolumn{2}{|l|}{ Pond } \\
\hline & $\begin{array}{l}\text { Mass } \\
\text { Frac. }\end{array}$ & $\begin{array}{l}\mathrm{U} \\
(+/-)\end{array}$ & $\begin{array}{l}\text { Mas } \\
\mathrm{s} \\
\text { Frac. }\end{array}$ & $\begin{array}{l}\text { U } \\
(+/-)\end{array}$ & $\begin{array}{l}\text { Mas } \\
\mathrm{s} \\
\text { Frac. }\end{array}$ & $\begin{array}{l}\text { U } \\
(+/-)\end{array}$ & $\begin{array}{l}\text { Mas } \\
\mathrm{s} \\
\text { Frac. }\end{array}$ & $\begin{array}{l}\text { U } \\
(+/-)\end{array}$ & $\begin{array}{l}\text { Mas } \\
\mathrm{s} \\
\text { Frac. }\end{array}$ & $\begin{array}{l}\text { U } \\
(+/-)\end{array}$ & $\begin{array}{l}\text { Mas } \\
\mathrm{s} \\
\text { Frac. }\end{array}$ & $\begin{array}{l}\mathrm{U} \\
(+/-)\end{array}$ & $\begin{array}{l}\text { Mass } \\
\text { Frac. }\end{array}$ & $\begin{array}{l}\text { U } \\
(+/-)\end{array}$ & $\begin{array}{l}\text { Mass } \\
\text { Frac. }\end{array}$ & $\begin{array}{l}\text { U } \\
(+/-)\end{array}$ \\
\hline Benzene & 0.01 & 0.01 & 0.01 & 0.01 & 0.00 & 0.01 & 0.11 & 0.03 & 0.16 & 0.02 & 0.43 & 0.06 & 0.29 & 0.08 & 0.03 & 0.01 \\
\hline Ethylbenzene & 0.10 & 0.05 & 0.03 & 0.01 & 0.02 & 0.01 & 0.00 & 0.01 & 0.08 & 0.01 & 0.05 & 0.01 & 0.00 & 0.00 & 0.05 & 0.03 \\
\hline Heptane & 0.21 & 0.08 & 0.24 & 0.04 & 0.45 & 0.20 & 0.05 & 0.01 & 0.03 & 0.01 & 0.04 & 0.01 & 0.00 & 0.00 & 0.23 & 0.08 \\
\hline Hexane & 0.07 & 0.03 & 0.24 & 0.06 & 0.11 & 0.05 & 0.22 & 0.05 & 0.05 & 0.01 & 0.10 & 0.02 & 0.08 & 0.17 & 0.20 & 0.07 \\
\hline $\begin{array}{l}\text { 2- } \\
\text { methylpentane }\end{array}$ & 0.03 & 0.01 & 0.09 & 0.02 & 0.09 & 0.04 & 0.60 & 0.13 & 0.07 & 0.01 & 0.01 & 0.00 & 0.46 & 0.23 & 0.07 & 0.03 \\
\hline Octane & 0.23 & 0.11 & 0.14 & 0.03 & 0.19 & 0.07 & 0.01 & 0.01 & 0.02 & 0.00 & 0.05 & 0.01 & 0.00 & 0.00 & 0.12 & 0.07 \\
\hline Toluene & 0.13 & 0.05 & 0.11 & 0.02 & 0.09 & 0.04 & 0.00 & 0.01 & 0.31 & 0.05 & 0.20 & 0.03 & 0.15 & 0.09 & 0.12 & 0.02 \\
\hline m,p-Xylene & 0.16 & 0.07 & 0.11 & 0.02 & 0.05 & 0.02 & 0.00 & 0.01 & 0.20 & 0.03 & 0.08 & 0.01 & 0.02 & 0.05 & 0.11 & 0.06 \\
\hline o-Xylene & 0.06 & 0.02 & 0.04 & 0.01 & 0.01 & 0.01 & 0.00 & 0.01 & 0.08 & 0.01 & 0.03 & 0.01 & 0.00 & 0.00 & 0.07 & 0.04 \\
\hline
\end{tabular}


Table S3: $\mathrm{OH}$ reaction-adjusted source profiles used in the CMB model

\begin{tabular}{|c|c|c|c|c|c|c|c|c|c|c|c|c|c|c|c|c|}
\hline \multirow[b]{2}{*}{ VOC } & \multicolumn{2}{|c|}{$\begin{array}{l}\text { Syncrude } \\
\text { (SML) }\end{array}$} & \multicolumn{2}{|c|}{$\begin{array}{l}\text { Suncor } \\
\text { (SUN) }\end{array}$} & \multicolumn{2}{|c|}{ CNRL } & \multicolumn{2}{|c|}{$\begin{array}{l}\text { Shell } \\
\text { (SAJ) }\end{array}$} & \multicolumn{2}{|c|}{ Gasoline } & \multicolumn{2}{|c|}{ Diesel } & \multicolumn{2}{|c|}{ Background } & \multicolumn{2}{|l|}{ Pond } \\
\hline & $\begin{array}{l}\text { Mass } \\
\text { Frac. }\end{array}$ & $\begin{array}{l}U \\
(+/-)\end{array}$ & $\begin{array}{l}\text { Mass } \\
\text { Frac. }\end{array}$ & $\begin{array}{l}\mathrm{U} \\
(+/-)\end{array}$ & $\begin{array}{l}\text { Mass } \\
\text { Frac. }\end{array}$ & $\begin{array}{l}\text { U } \\
(+/-)\end{array}$ & $\begin{array}{l}\text { Mass } \\
\text { Frac. }\end{array}$ & $\begin{array}{l}\mathrm{U} \\
(+/-)\end{array}$ & $\begin{array}{l}\text { Mass } \\
\text { Frac. }\end{array}$ & $\begin{array}{l}\mathrm{U} \\
(+/-)\end{array}$ & $\begin{array}{l}\text { Mass } \\
\text { Frac. }\end{array}$ & $\begin{array}{l}\mathrm{U} \\
(+/-)\end{array}$ & $\begin{array}{l}\text { Mass } \\
\text { Frac. }\end{array}$ & $\begin{array}{l}\mathrm{U} \\
(+/-)\end{array}$ & $\begin{array}{l}\text { Mass } \\
\text { Frac. }\end{array}$ & $\begin{array}{l}\mathrm{U} \\
(+/-)\end{array}$ \\
\hline Benzene & 0.02 & 0.01 & 0.02 & 0.01 & 0.00 & 0.01 & 0.12 & 0.03 & 0.16 & 0.02 & 0.43 & 0.06 & 0.29 & 0.08 & 0.04 & 0.01 \\
\hline Ethylbenzene & 0.10 & 0.05 & 0.03 & 0.01 & 0.02 & 0.01 & 0.00 & 0.01 & 0.08 & 0.01 & 0.05 & 0.01 & 0.00 & 0.00 & 0.05 & 0.03 \\
\hline Heptane & 0.21 & 0.08 & 0.24 & 0.04 & 0.46 & 0.20 & 0.05 & 0.01 & 0.03 & 0.01 & 0.04 & 0.01 & 0.00 & 0.00 & 0.23 & 0.08 \\
\hline Hexane & 0.07 & 0.03 & 0.25 & 0.06 & 0.11 & 0.05 & 0.22 & 0.05 & 0.05 & 0.01 & 0.10 & 0.02 & 0.08 & 0.17 & 0.21 & 0.07 \\
\hline $\begin{array}{l}\text { 2- } \\
\text { methylpentane }\end{array}$ & 0.03 & 0.01 & 0.09 & 0.02 & 0.09 & 0.03 & 0.59 & 0.13 & 0.07 & 0.01 & 0.01 & 0.00 & 0.46 & 0.23 & 0.07 & 0.03 \\
\hline Octane & 0.23 & 0.11 & 0.14 & 0.03 & 0.19 & 0.07 & 0.01 & 0.01 & 0.02 & 0.00 & 0.05 & 0.01 & 0.00 & 0.00 & 0.12 & 0.06 \\
\hline Toluene & 0.14 & 0.05 & 0.11 & 0.02 & 0.09 & 0.04 & 0.00 & 0.01 & 0.31 & 0.05 & 0.20 & 0.03 & 0.15 & 0.09 & 0.12 & 0.02 \\
\hline m,p-Xylene & 0.14 & 0.06 & 0.10 & 0.02 & 0.04 & 0.02 & 0.00 & 0.01 & 0.20 & 0.03 & 0.08 & 0.01 & 0.02 & 0.05 & 0.10 & 0.05 \\
\hline o-Xylene & 0.06 & 0.02 & 0.04 & 0.01 & 0.01 & 0.01 & 0.00 & 0.01 & 0.08 & 0.01 & 0.03 & 0.01 & 0.00 & 0.00 & 0.06 & 0.03 \\
\hline
\end{tabular}




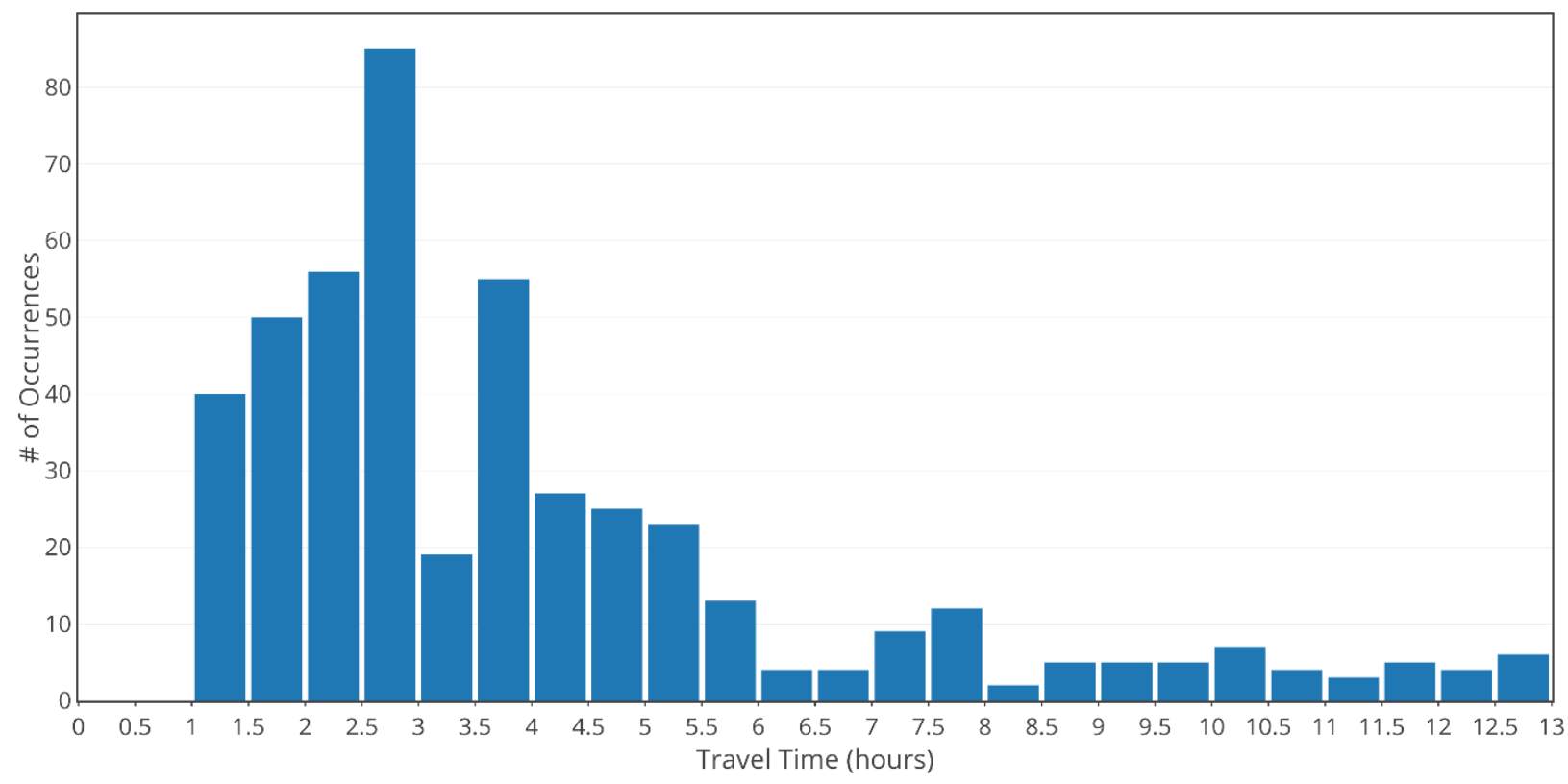

Figure S16: Model derived histogram of transit times from Pond $2 / 3$ to Fort McKay. An occurrence is defined as the number of calculated paths that fall in the specific time bin.

\section{S6.1.2 CMB Output}

High-VOC events were defined by periods for which total organic mass concentration (TOC) exceeded the $90^{\text {th }}$ percentile threshold $\left(13.6 \mu \mathrm{g} \mathrm{m}^{-3}\right)$ for at least two consecutive 30-min measurements $(\geq 1 \mathrm{~h})$. The start and end times of the events were identified as those instances in which TOC concentration crossed this threshold. A total of 169 high-VOC events were identified using this criterion. The model output was considered good (well-fit) when $\mathrm{R}^{2} \geq 0.8, \chi^{2} \leq 4.0$, and $80 \leq \%$ mass (percent of observed mass explained) $\leq 120 \%$, simultaneously. Nearly $80 \%$ of the 30-minute instances converged with a good fit when $\mathrm{OH}$ reaction-adjusted profiles were used. 


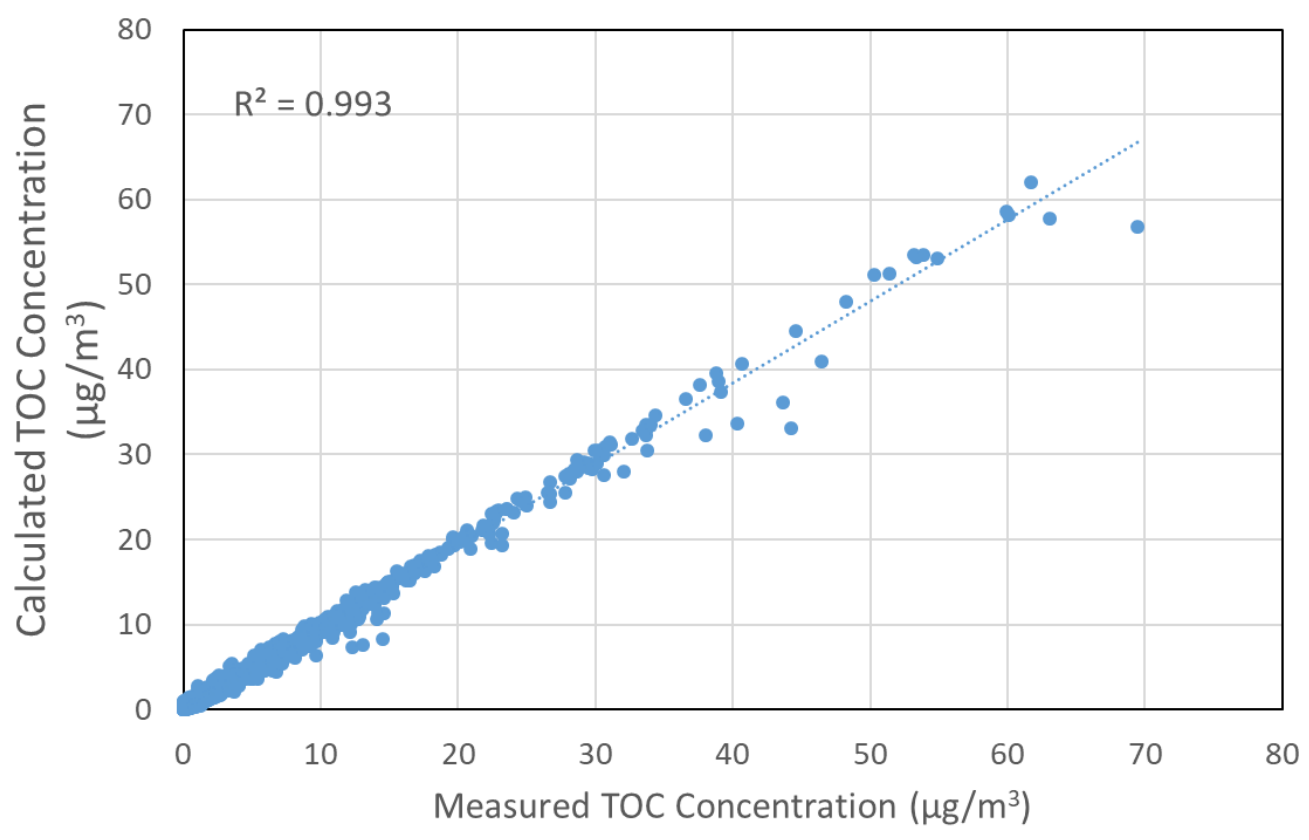

Figure S17: A correlation plot between total organic carbon (TOC) calculated by CMB and TOC measured at FMK. TOC represents the sum of the 9 VOCs represented in the CMB analysis. 


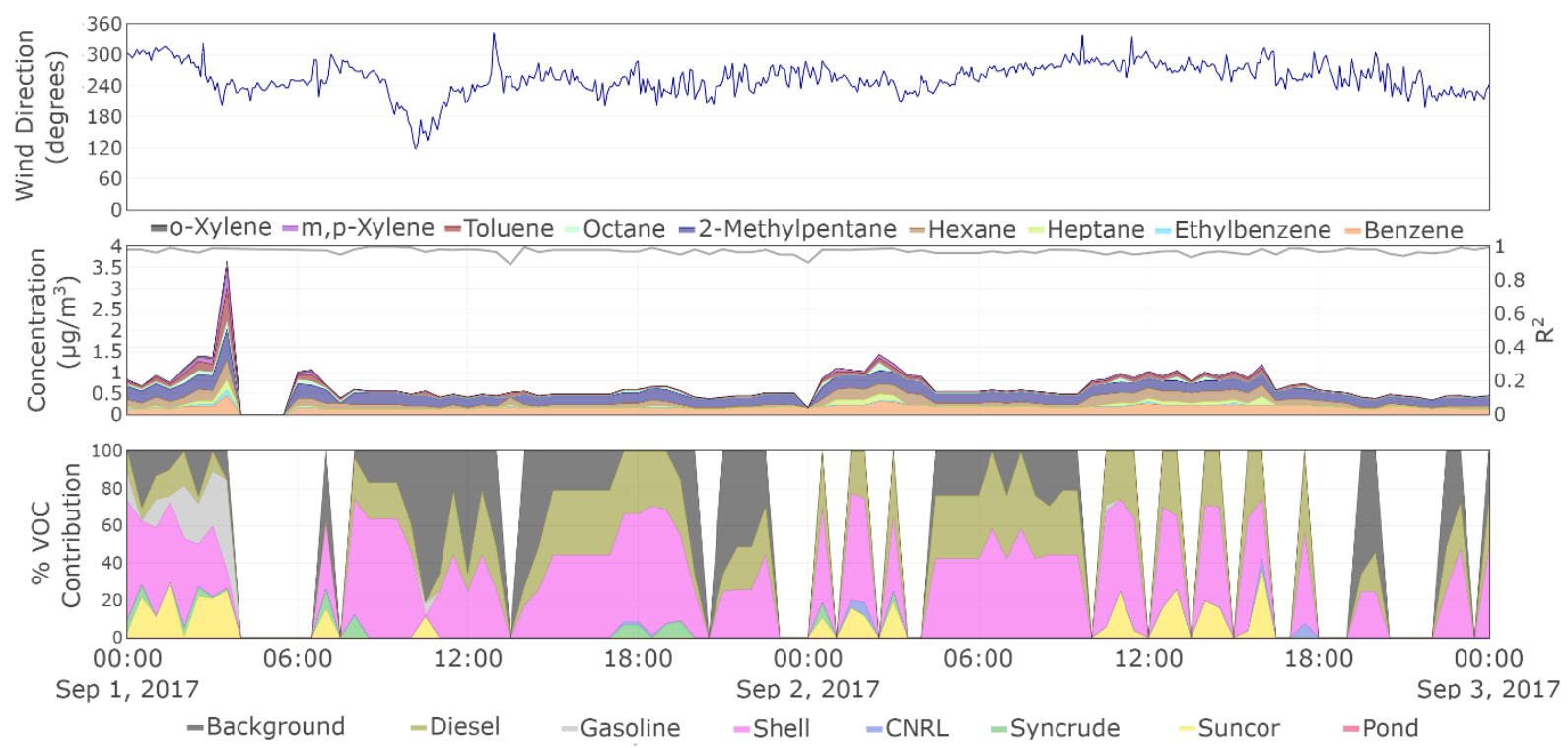

Figure S18: CMB results from FMK for the September 1 - September 2, 2017 period, which show: A) the wind direction measured at FMK; B) the concentrations $\left(\mu \mathrm{g} / \mathrm{m}^{3}\right)$ of the nine VOCs sampled at FMK. Note that $\mathrm{R}^{2}$ represents the correlation between total organic carbon (TOC) measured and TOC calculated based on CMB results). C) percent contribution form the different source profiles, Shell, diesel, ambient background and gasoline were the major contributors to the VOCs events in FMK during this period, when the winds were from the west and north.

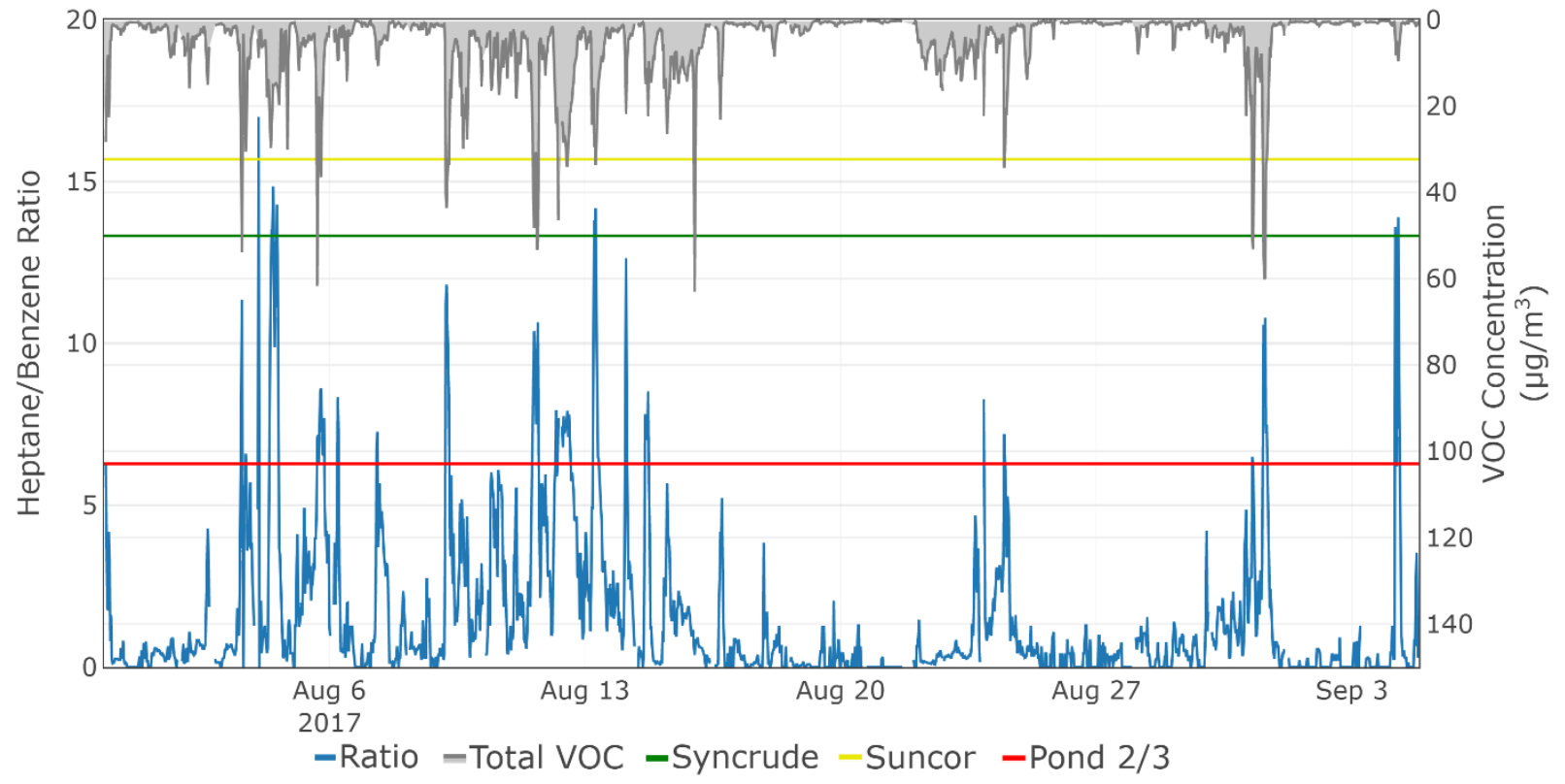


Figure S19: Measured Heptane/Benzene ratio at FMK during the study period (blue). The top grey trace represents the total VOCs measured at FMK in $\mu \mathrm{g} / \mathrm{m}^{3}$. The solid line tracers represents the Heptane/Benzene ratio from Pond 2/3 (purple), Suncor (red) and Syncrude (green).

\section{S7 Wind Transport Model}

\section{S7.1 Data}

At 12 monitoring stations surrounding Pond 2/3 and Fort McKay, wind speed and wind direction were measured continuously from July $31^{\text {st }}$ to September $5^{\text {th }}, 2017$. Ten stations were managed by the Wood Buffalo Environmental Association (WBEA) and the remaining two stations were managed by Environment and Climate Change Canada. The geographical coordinates of each station are provided in Table S4. Measurements were averaged to 5-minute intervals.

Table S4: Station locations

\begin{tabular}{|l|l|l|l|}
\hline Station Name & Station ID & Longitude & Latitude \\
\hline Buffalo Viewpoint & AMS04 & -111.594 & 56.99627 \\
\hline Fort McKay South & AMS13 & -111.642 & 57.14918 \\
\hline Mannix & AMS05 & -111.482 & 56.96796 \\
\hline Bertha Ganter & AMS01 & -111.641 & 57.18943 \\
\hline Lower Camp & AMS11 & -111.501 & 57.02679 \\
\hline Lower Camp MET & AMS03 & -111.506 & 57.03248 \\
\hline Mildred Lake & AMS02 & -111.564 & 57.05001 \\
\hline Fort McKay (Oski-ôtin) & N/A & -111.64 & 57.18366 \\
\hline Pond 2/3 & N/A & -111.508 & 56.98361 \\
\hline
\end{tabular}




\begin{tabular}{|l|l|l|l|}
\hline $\begin{array}{l}\text { Waskow ohci } \\
\text { Pimatisiwin }\end{array}$ & AMS25 & -111.639 & 57.18367 \\
\hline Horizon & AMS15 & -111.739 & 57.30369 \\
\hline Fort Hills & AMS23 & -111.64 & 57.3489 \\
\hline
\end{tabular}

\section{S7.2 Wind Transport Model Methodology}

The model is designed to calculate the travel path of a theoretical air parcel. Every path calculated by the model ends in Fort McKay. The model utilizes a back-trace approach in which the data available is used to determine the point on the path 5-minutes prior. To do this, first a wind surface is generated by kriging, using the data from all 12 stations ${ }^{22}$ Kriging (Krige, 1966) is a 2dimensional geostatistical interpolation method that predicts values in unknown locations using measured data. ${ }^{22}$ The measured data values are linearly combined and weighted based on distance and spatial arrangement. Luo et al. (2008) performed a comprehensive comparison of various spatial interpolation methods for wind data and found ordinary kriging to be one of the more accurate methods that did not require covariates in the estimation. ${ }^{23}$ Ordinary kriging assumes the mean value is unknown and, thus, relies solely on the measured values. Once these surfaces are generated, the travel distance and direction of an air parcel after 5 minutes is calculated based on its current position in the wind surface. This is continuously repeated until the air parcel reaches one of the spatial boundaries. The northern and southern spatial boundaries were defined as the most northern and southern monitoring stations (AMS23 and AMS05, respectively). The eastern and western spatial boundaries are similarly defined (AMS15 and AMS11), though an extra five kilometers in each of these directions was applied due to the narrow spatial domain that would otherwise result. Once a path is fully determined, the location of each point along the path is compared to source boundaries to determine if the path crossed over the air space of one or multiple sources. The spatial boundaries of the facilities are based on GIS polygons representative of the year 2013. The pond $2 / 3$ polygon is a simple box ( 3 kilometers by 2 kilometers) surrounding the pond edges. If a path contains at least one point falling within the boundaries of one or more sources, the path is labelled with those sources as potential causes for the measured VOCs in Fort McKay at the time the path arrives in Fort McKay. A path with an end-point of Fort McKay was generated every 5 minutes using this process.

\section{S7.3 Wind Path Map Description}

Figure S20 shows paths that crossed over the pond (red) and Fort McKay (blue) during TAPOS (Aug 02 -Aug 31 2017). The Suncor (yellow) and Syncrude (green) facilities are also shown. This highlights the likeliness of multiple sources affecting the observed VOC concentrations at Fort MacKay. A maximum of one path per hour is shown to highlight unique paths and increase clarity. Our wind transport model was developed to improve the backward trajectories analysis by taking into account high-resolution spatial and temporal wind data, which also considers the topography 
of the region, that are not otherwise accounted for by the HYSPLIT model. As a proof of this concept, figure S21 shows that the wind back-trajectories created using the wind transport model compare very well with those generated using the HYSPLIT model for the Aug 12-Aug14 period, but provides finer resolution details.

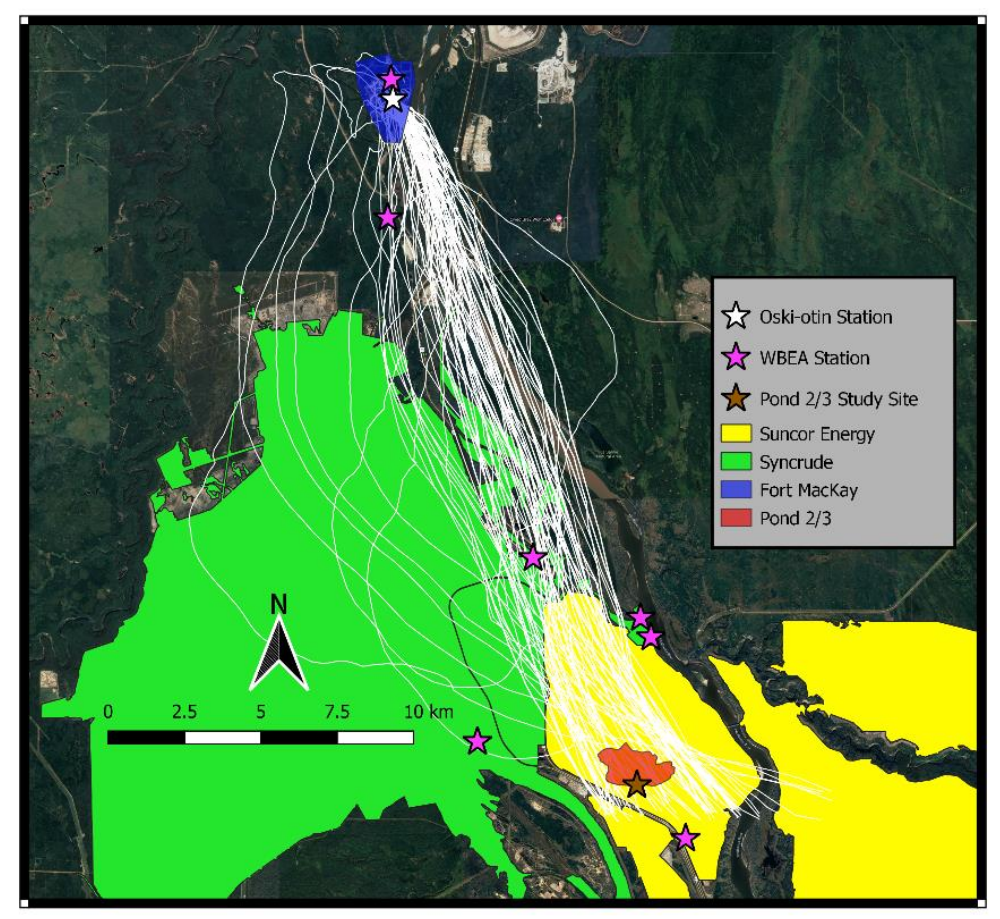

Figure S20: Wind back trajectories crossing Fort MacKay (blue) and Pond 2/3 (red) from Aug 02 to Aug 31, 2017 created using the wind transport model. 

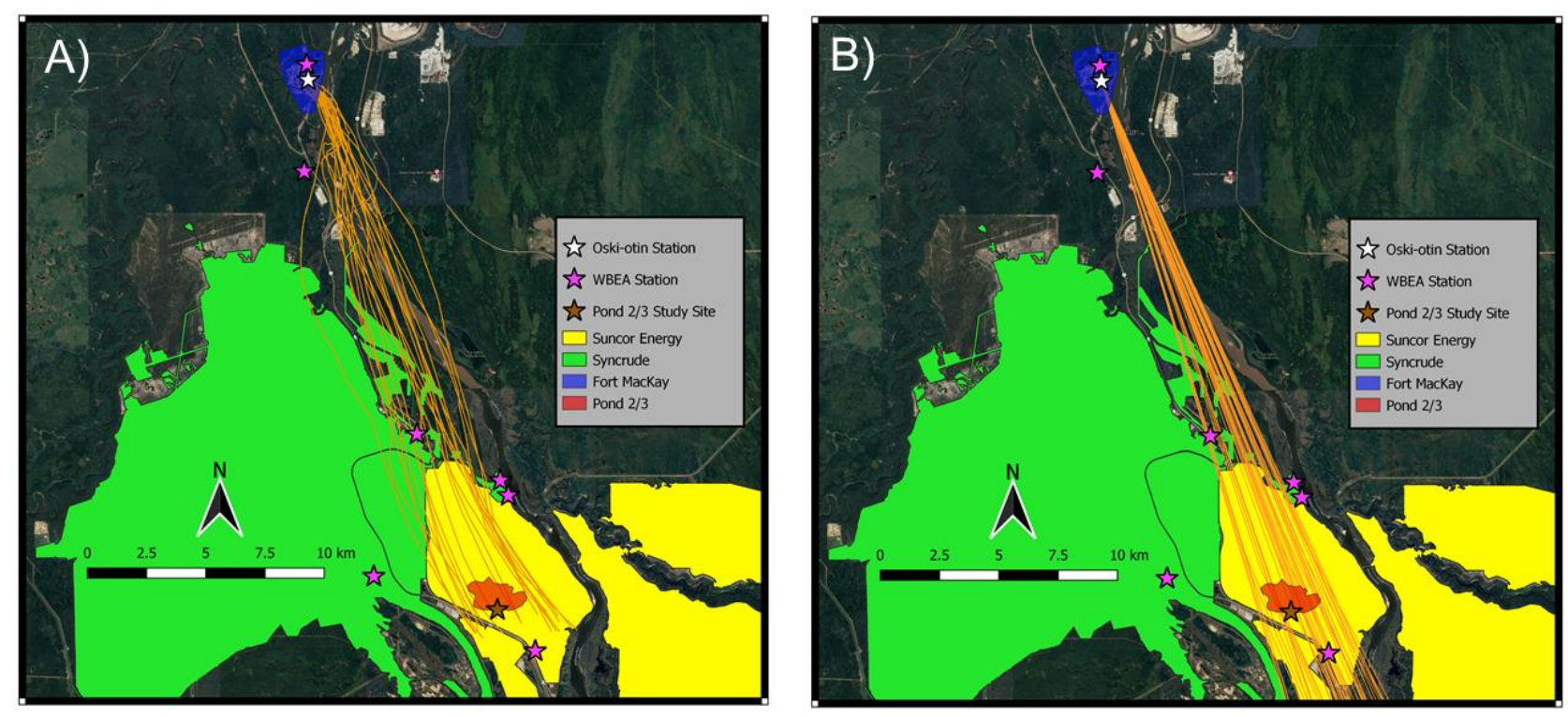

Figure S21: A comparison of wind back trajectories crossing Fort MacKay and Pond 2/3 between Aug12-Aug14, 2017 between A) the wind transport model and B) HYSPLIT back trajectory model. 
Table S5: VOCs Speciation from PTR-MS.

\begin{tabular}{|c|c|}
\hline Chemical Structure & Possible Compound \\
\hline $\mathrm{CH}_{4} \mathrm{O}$ & Methanol \\
\hline $\mathrm{C}_{2} \mathrm{H}_{3} \mathrm{~N}$ & Acetonitrile \\
\hline $\mathrm{C} 2 \mathrm{H} 4 \mathrm{O}$ & Acetaldehyde \\
\hline $\mathrm{C}_{2} \mathrm{H}_{6} \mathrm{~S}$ & Dimethylsulfide \\
\hline $\mathrm{C}_{3} \mathrm{H}_{4} \mathrm{O}$ & Acrolein \\
\hline $\mathrm{C}_{3} \mathrm{H}_{6} \mathrm{O}$ & Acetone + Propanal \\
\hline $\mathrm{C}_{3} \mathrm{H}_{8} \mathrm{~S}$ & Ethylmethylsulfide \\
\hline $\mathrm{C}_{4} \mathrm{H}_{4} \mathrm{~S}$ & Thiophene \\
\hline $\mathrm{C}_{4} \mathrm{H}_{6} \mathrm{O}$ & MVK + MACR \\
\hline $\mathrm{C}_{4} \mathrm{H}_{8} \mathrm{O}$ & MEK \\
\hline $\mathrm{C}_{4} \mathrm{H}_{10} \mathrm{~S}$ & Diethyl Sulfide \\
\hline $\mathrm{C}_{5} \mathrm{H}_{6} \mathrm{~S}$ & 2- MethylThiophene \\
\hline $\mathrm{C}_{5} \mathrm{H}_{8}$ & Isoprene + alkane fragment + cycloalkene \\
\hline $\mathrm{C}_{6} \mathrm{H}_{6}$ & Benzene \\
\hline $\mathrm{C}_{6} \mathrm{H}_{8} \mathrm{~S}$ & Dihydrothiophene, Dimethythiophene, Ethylthiophene \\
\hline $\mathrm{C}_{7} \mathrm{H}_{8}$ & Toluene \\
\hline $\mathrm{C}_{8} \mathrm{H}_{10}$ & $\mathrm{C} 8$ aromatics \\
\hline $\mathrm{C}_{10} \mathrm{H}_{16}$ & Monoterpenes + Adamantane \\
\hline $\mathrm{C}_{11} \mathrm{H}_{12}$ & unknown \\
\hline $\mathrm{C}_{10} \mathrm{H}_{12}$ & EthylStyrene, Bytenyl benzene isomers, Methyl Indane \\
\hline $\mathrm{C}_{10} \mathrm{H}_{10}$ & Dihydronaphthalene \\
\hline $\mathrm{C}_{12} \mathrm{H}_{14}$ & Unknown \\
\hline $\mathrm{C}_{12} \mathrm{H}_{12}$ & C2-substituted naphthalenes \\
\hline $\mathrm{C}_{11} \mathrm{H}_{14}$ & Substituted Benzenes \\
\hline $\mathrm{C}_{8} \mathrm{H}_{8}$ & Styrene \\
\hline $\mathrm{C}_{6} \mathrm{H}_{12}$ & Unknown, Methyl Cyclopentane, Cyclohexane \\
\hline $\mathrm{C}_{6} \mathrm{H}_{10}$ & Unknown \\
\hline $\mathrm{C}_{5} \mathrm{H}_{10}$ & Pentenes+ Methyl Butenes \\
\hline $\mathrm{C}_{9} \mathrm{H}_{12}$ & C9 aromatics \\
\hline $\mathrm{C}_{9} \mathrm{H}_{16}$ & Unknown, C9 Cycloalkanes+ secondary species fragments \\
\hline $\mathrm{C}_{8} \mathrm{H}_{14}$ & C8 cycloalkanes + secondary species fragments \\
\hline $\mathrm{C}_{7} \mathrm{H}_{12}$ & Unknown \\
\hline $\mathrm{C}_{12} \mathrm{H}_{16}$ & Unknown \\
\hline $\mathrm{C}_{11} \mathrm{H}_{16}$ & $\mathrm{C} 11$ aromatics \\
\hline $\mathrm{C}_{9} \mathrm{H}_{10}$ & Methyl styrene, Propenylbenzene, Methyethylbenzene, Indane \\
\hline $\mathrm{C}_{11} \mathrm{H}_{10}$ & Methyl naphthalene \\
\hline $\mathrm{C}_{10} \mathrm{H}_{8}$ & Naphthalene \\
\hline $\mathrm{C}_{10} \mathrm{H}_{14}$ & $\mathrm{C} 10$ aromatics \\
\hline $\mathrm{C}_{11} \mathrm{H}_{18}$ & Unknown, Methyl adamantane \\
\hline $\mathrm{C}_{8} \mathrm{H}_{16}$ & Unknown, Propylcyclopentane \\
\hline
\end{tabular}




\begin{tabular}{|l|l|}
\hline $\mathrm{C}_{7} \mathrm{H}_{14}$ & Unknown, Ethylcyclopentane or Methylcyclohexane, Propylcyclopentane \\
$\mathrm{C}_{12} \mathrm{H}_{10}$ & Unknown \\
$\mathrm{C}_{12} \mathrm{H}_{18}$ & C12 aromatics \\
$\mathrm{C}_{6} \mathrm{H}_{12}$ & 2-methyl-2-pentene \\
$\mathrm{C}_{7} \mathrm{H}_{10} \mathrm{~S}$ & Trimethyl thiophene or Propyl thiophene \\
$\mathrm{C}_{8} \mathrm{H}_{12} \mathrm{~S}$ & ButylThiophene \\
\hline
\end{tabular}

Table S6: Pond $2 / 3$ area sectors divided by $22.5^{\circ}$ bins. The shaded cells represent the pond sector direction.

\begin{tabular}{|c|c|c|c|}
\hline Sector Center $\left({ }^{\circ}\right)$ & Sector Start $\left({ }^{\circ}\right)$ & Sector End ( $)$ & Area $\left(\mathbf{m}^{\mathbf{2}}\right)$ \\
\hline 0 & 348.75 & 11.25 & 247507 \\
\hline 22.5 & 11.25 & 33.75 & 240957 \\
\hline 45 & 33.75 & 56.25 & 284245 \\
\hline 67.5 & 56.25 & 78.75 & 255363 \\
\hline 90 & 78.75 & 101.25 & 15875 \\
\hline 112.5 & 101.25 & 123.75 & NA \\
\hline 135 & 123.75 & 146.25 & NA \\
\hline 157.5 & 146.25 & 168.75 & NA \\
\hline 180 & 168.75 & 191.25 & NA \\
\hline 202.5 & 191.25 & 213.75 & NA \\
\hline 225 & 213.75 & 236.25 & NA \\
\hline 247.5 & 236.25 & 258.75 & NA \\
\hline 270 & 258.75 & 281.25 & 181317 \\
\hline 292.5 & 281.25 & 303.75 & 398978 \\
\hline 315 & 303.75 & 326.25 & 369215 \\
\hline 337.5 & 326.25 & 348.75 & 340237 \\
\hline Total Area & & & $\mathbf{2 3 3 3 6 9 4}$ \\
\hline
\end{tabular}

\section{S8. Kc Calculation}

Gradient Fluxes for the VOC were calculated based on the following equation

$$
\operatorname{Flux}_{i}=-K_{c}\left(\frac{d c}{d z}\right)_{\mathrm{i}}
$$

where $K_{\mathrm{c}}$ is the eddy diffusivity coefficient, and dc/dz is the concentration gradient of $\mathrm{VOC}_{\mathrm{i}}$ between z=32 m and z=8m. $K_{c}$ estimation is discussed in details in You et al. 2021. ${ }^{2}$ Briefly, $K_{c}$ was calculated using eddy covariance (EC) methane measurements at $18 \mathrm{~m}$ and gradient methane measurements between $8 \mathrm{~m}$ and $32 \mathrm{~m}$, representing an equivalent footprint to as the EC fluxes at $18 \mathrm{~m}$. Since $\mathrm{CH}_{4}$ flux data were more intermittent than momentum flux data the latter were used 
to provide a more continuous measure of the eddy diffusivity by calculating $K_{c}$ from $K_{m}$ and the Schmidt Number (Sc) as shown in equations (2) and (3). As detailed by You et al 2021, ${ }^{2} S c$ as defined in our calculations incorporated a stability correction.

$F_{m}=-K_{m} \frac{\partial u}{\partial z}$

$S_{c}=\frac{K_{m}}{K_{c}}$

\section{S9. Flux uncertainty estimation}

The time series for VOC gradient fluxes when the wind was coming from the pond direction showed many fluctuations. In order to estimate the total uncertainty for the gradient fluxes, the standard deviation $( \pm 1 \sigma)$ and the relative standard deviation were calculated for periods that showed consistent fluxes and meteorological conditions, to provide a "top-down" integrated error estimate.

The uncertainty calculation for the canister VOC fluxes was obtained using the equation below:

$$
\text { Uncertainty }_{V O C}=\sqrt{a^{2}+b^{2}+c^{2}+d^{2}}
$$

Where:

$\mathrm{a}=$ the error associated with canister VOC concentration

$b=$ the error associated with the tracer VOC concentration

$\mathrm{c}=$ the error associated with the ratio determined from the slope of the correlation of the concentration of the canister VOC with that of the tracer

$\mathrm{d}=$ the error associated with the flux of the tracer. 
Table S7: Emission rates of VOC $\left(\mathrm{g} \mathrm{m}^{-2} \mathrm{~d}^{-1}\right)$ based on gradient flux measurements

\begin{tabular}{|c|c|c|c|c|c|}
\hline & \multicolumn{4}{|c|}{ Pond Direction } & \multirow{3}{*}{$\begin{array}{c}\text { Other Directions } \\
\text { Flux }\left(\mathbf{g ~ m}^{-2} \mathbf{d}^{-\mathbf{1}}\right) \\
\text { mean }\end{array}$} \\
\hline & \multicolumn{4}{|c|}{ Flux $\left(\mathrm{g} \mathrm{m}^{-2} \mathbf{d}^{-1}\right)$} & \\
\hline & mean & $25 \%$ & Median & $75 \%$ & \\
\hline Formaldehyde & 0.01738 & -0.0243 & 0.015 & 0.05125 & 0.2935 \\
\hline Ethane & 0.12263 & -0.0435 & 0.04663 & 0.29988 & 0.03325 \\
\hline Methanol & 0.00713 & 0.00213 & 0.00663 & 0.01138 & 0.00325 \\
\hline Acetonitrile & 0.00425 & 0.00113 & 0.00313 & 0.0055 & 0.00025 \\
\hline MACR+MVK & 0.00188 & -0.0005 & 0.00138 & 0.003 & 0.000875 \\
\hline Benzene & 0.0695 & 0.02888 & 0.05688 & 0.09463 & 0.001 \\
\hline Toluene & 0.24125 & 0.09375 & 0.19075 & 0.32063 & 0.002625 \\
\hline Ethyl Benzene + Xylenes & 0.41425 & 0.16938 & 0.333 & 0.5545 & 0.003875 \\
\hline $\mathrm{C}_{5} \mathrm{H}_{8}$ & 0.2225 & 0.10625 & 0.17975 & 0.299 & 0.01525 \\
\hline Acrolein & 0.0015 & -0.0003 & 0.00113 & 0.00263 & 0.000375 \\
\hline Acetaldehyde & 0.00588 & 0.0025 & 0.0045 & 0.008 & 0.00225 \\
\hline Acetone and Propanal & 0.0185 & 0.00888 & 0.01525 & 0.02613 & 0.0035 \\
\hline MEK + Butanal & 0.01613 & 0.00775 & 0.01288 & 0.02263 & 0.000875 \\
\hline Thiophene & 0.00213 & 0.00075 & 0.00163 & 0.00313 & 0 \\
\hline $\begin{array}{l}\text { Dimethyl Sulfide + Ethyl } \\
\text { Mercaptan }\end{array}$ & 0.00025 & -0.0005 & 0.00013 & 0.00088 & 0.000125 \\
\hline Methyl Thiophene & 0.01688 & 0.00663 & 0.01375 & 0.02438 & 0.000125 \\
\hline Diethyl Sulfide & 0.09638 & 0.03963 & 0.07863 & 0.13463 & 0.0015 \\
\hline Dimethyl Thiophene & 0.048 & 0.02313 & 0.04125 & 0.065 & 0.001 \\
\hline Ethyl Methyl Sulfide & 0.00375 & 0.00113 & 0.003 & 0.00538 & 0.000125 \\
\hline
\end{tabular}




\begin{tabular}{|c|c|c|c|c|c|}
\hline $\mathrm{C}_{10} \mathrm{H}_{16}$ & 0.05713 & 0.03 & 0.05013 & 0.07313 & 0.004625 \\
\hline $\mathrm{C}_{10} \mathrm{H}_{12}$ & 0.01675 & 0.00669 & 0.01493 & 0.02289 & 0.0002825 \\
\hline $\mathrm{C}_{12} \mathrm{H}_{18}$ & 0.007 & 0.00321 & 0.0059 & 0.00969 & 0.000325 \\
\hline $\mathrm{C}_{9} \mathrm{H}_{16}$ & 0.02087 & 0.00824 & 0.01756 & 0.02872 & 0.00056375 \\
\hline $\mathrm{C}_{11} \mathrm{H}_{16}$ & 0.01376 & 0.00579 & 0.01132 & 0.01891 & 0.0004125 \\
\hline $\mathrm{C}_{12} \mathrm{H}_{16}$ & 0.00374 & 0.00181 & 0.00342 & 0.00515 & 0.000115 \\
\hline $\mathrm{C}_{10 \mathrm{H}_{10}}$ & 0.00303 & 0.00117 & 0.00263 & 0.00417 & 0.0000525 \\
\hline $\mathrm{C}_{12} \mathrm{H}_{10}$ & 0.00187 & 0.00059 & 0.00157 & 0.00289 & 0.000035 \\
\hline $\mathrm{C}_{7} \mathrm{H}_{14}$ & 0.00549 & 0.00241 & 0.00458 & 0.0077 & 0.000125 \\
\hline $\mathrm{C}_{8} \mathrm{H}_{16}$ & 0.0046 & 0.00163 & 0.00388 & 0.00686 & 0.0001175 \\
\hline $\mathrm{C}_{11 \mathrm{H}_{18}}$ & 0.01076 & 0.00492 & 0.00922 & 0.01468 & 0.00040875 \\
\hline $\mathrm{C}_{9} \mathrm{H}_{10}$ & 0.01921 & 0.00757 & 0.01706 & 0.02643 & 0.0003075 \\
\hline $\mathrm{C}_{11} \mathrm{H}_{10}$ & 0.00094 & 0.00024 & 0.00074 & 0.00146 & 0.00004125 \\
\hline $\mathrm{C}_{10} \mathrm{H}_{8}$ & 0.00235 & 0.00095 & 0.00212 & 0.00343 & 0.00002 \\
\hline $\mathrm{C}_{10 \mathrm{H}_{14}}$ & 0.0498 & 0.02021 & 0.04193 & 0.07051 & 0.0009125 \\
\hline $\mathrm{C}_{9 \mathrm{H}_{12}}$ & 0.15865 & 0.05712 & 0.13741 & 0.22315 & 0.0018925 \\
\hline $\mathrm{C}_{8} \mathrm{H}_{14}$ & 0.04681 & 0.01958 & 0.03981 & 0.06517 & 0.0015 \\
\hline $\mathrm{C}_{7} \mathrm{H}_{12}$ & 0.07308 & 0.03202 & 0.06197 & 0.10208 & 0.00262125 \\
\hline $\mathrm{C}_{8} \mathrm{H}_{8}$ & 0.01402 & 0.00555 & 0.01178 & 0.01902 & 0.00036375 \\
\hline $\mathrm{C}_{6} \mathrm{H}_{12}$ & 0.03244 & 0.01243 & 0.02521 & 0.04424 & 0.00086125 \\
\hline $\mathrm{C}_{6} \mathrm{H}_{10}$ & 0.09747 & 0.04042 & 0.0781 & 0.13654 & 0.00350875 \\
\hline $\mathrm{C}_{5} \mathrm{H}_{10}$ & 0.06524 & 0.0224 & 0.04926 & 0.088 & 0.00226375 \\
\hline $\mathrm{C}_{12} \mathrm{H}_{14}$ & 0.00106 & 0.00048 & 0.0009 & 0.00158 & 0.000005 \\
\hline $\mathrm{C}_{12} \mathrm{H}_{12}$ & 0.00144 & 0.00064 & 0.00134 & 0.00199 & 0.00004125 \\
\hline $\mathrm{C}_{11} \mathrm{H}_{14}$ & 0.00828 & 0.00341 & 0.0073 & 0.01142 & 0.00019 \\
\hline $\mathrm{C}_{11} \mathrm{H}_{12}$ & 0.00116 & 0.00034 & 0.00108 & 0.00169 & 0.0000075 \\
\hline $\mathrm{C}_{7} \mathrm{H}_{10} \mathrm{~S}$ & 0.01735 & 0.0061 & 0.01534 & 0.02457 & 0.00016625 \\
\hline $\mathrm{C}_{8} \mathrm{H}_{12} \mathrm{~S}$ & 0.00678 & 0.00286 & 0.00623 & 0.00935 & 0.00008 \\
\hline
\end{tabular}



Table S8: Emission rates of canister VOC $\left(\mathrm{g} \mathrm{m}^{-2} \mathrm{~d}^{-1}\right)$ derived from gradient flux measurements

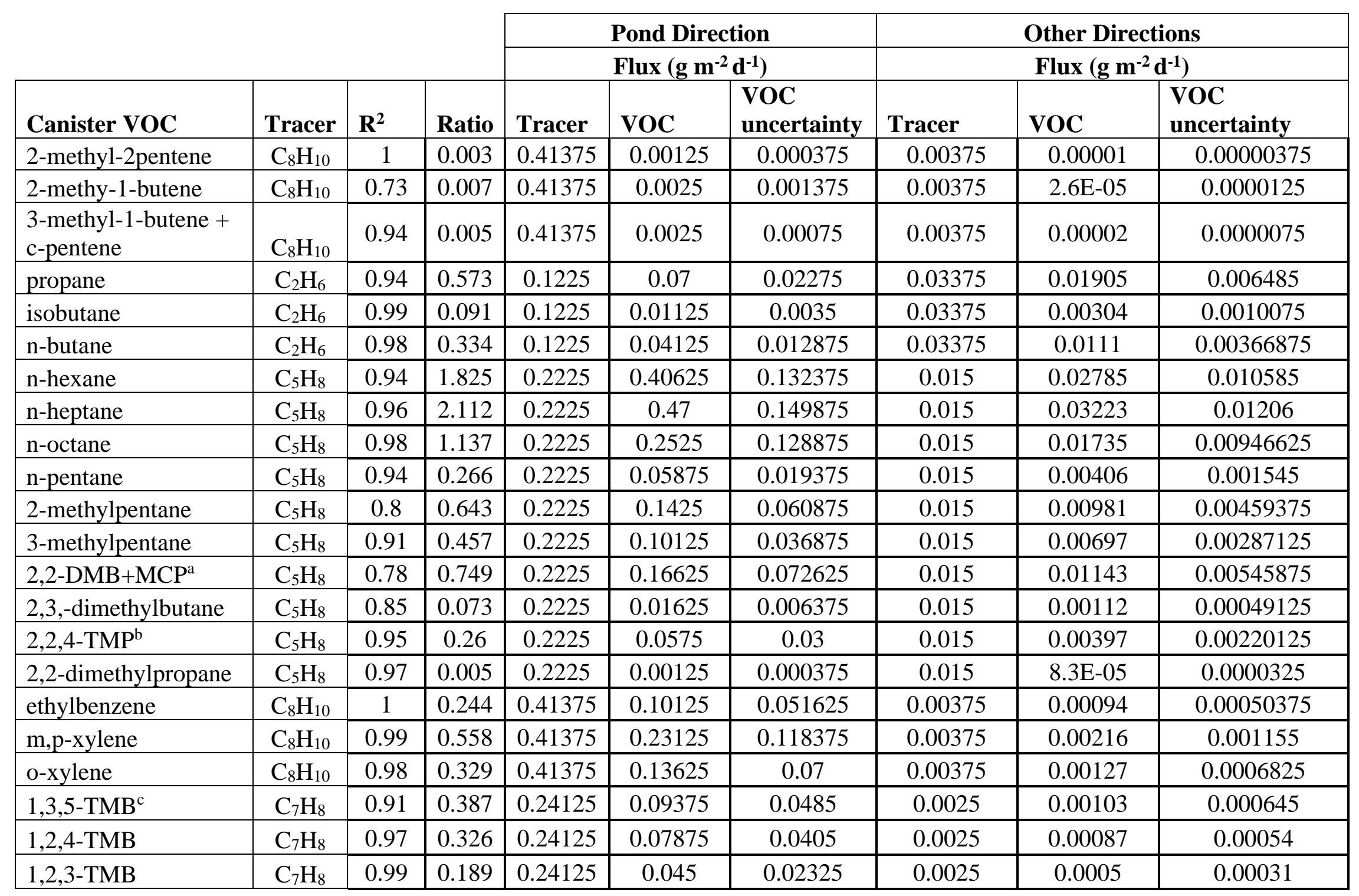

${ }^{\mathrm{a}} \mathrm{DMB}$ and CMP stand for dimethylbutane and methylcyclopentane, respectively. ${ }^{\mathrm{b}} \mathrm{TMP}$ stands for trimethylpentane. ${ }^{\mathrm{c}} \mathrm{TMB}$ stands for trimethylbenzene 



\section{References}

1. Sekimoto, K.; Li, S.-M.; Yuan, B.; Koss, A.; Coggon, M.; Warneke, C.; de Gouw, J., Calculation of the sensitivity of proton-transfer-reaction mass spectrometry (PTR-MS) for organic trace gases using molecular properties. Int. J. Mass Spectrom. 2017, 421, 71-94.

2. You, Y.; Staebler, R. M.; Moussa, S. G.; Beck, J.; Mittermeier, R. L., Methane emission from an oil sands tailings pond: A quantitative comparison of fluxes derived by different methods. Atmos. Meas. Tech. 2021, 14, 1879-1892.

3. $\quad$ Kort, E. A.; Smith, M. L.; Murray, L. T.; Gvakharia, A.; Brandt, A. R.; Peischl, J.; Ryerson, T. B.; Sweeney, C.; Travis, K., Fugitive emissions from the Bakken shale illustrate role of shale production in global ethane shift. Geophys. Res. Lett. 2016, 43, (9), 4617-4623.

4. $\quad$ Koss, A.; Yuan, B.; Warneke, C.; Gilman, J. B.; Lerner, B. M.; Veres, P. R.; Peischl, J.; Eilerman, S.; Wild, R.; Brown, S. S.; Thompson, C. R.; Ryerson, T.; Hanisco, T.; Wolfe, G. M.; Clair, J. M. S.; Thayer, M.; Keutsch, F. N.; Murphy, S.; de Gouw, J., Observations of VOC emissions and photochemical products over US oil- and gas-producing regions using highresolution H3O+ CIMS (PTR-ToF-MS). Atmos. Meas. Tech. 2017, 10, (8), 2941-2968.

5. $\quad$ Koss, A. R.; Sekimoto, K.; Gilman, J. B.; Selimovic, V.; Coggon, M. M.; Zarzana, K. J.; Yuan, B.; Lerner, B. M.; Brown, S. S.; Jimenez, J. L.; Krechmer, J.; Roberts, J. M.; Warneke, C.; Yokelson, R. J.; de Gouw, J., Non-methane organic gas emissions from biomass burning: identification, quantification, and emission factors from PTR-ToF during the FIREX 2016 laboratory experiment. Atmos. Chem. Phys. 2018, 18, (5), 3299-3319.

6. Koss, A. R.; Warneke, C.; Yuan, B.; Coggon, M. M.; Veres, P. R.; de Gouw, J. A., Evaluation of $\mathrm{NO}+$ reagent ion chemistry for online measurements of atmospheric volatile organic compounds. Atmos. Meas. Tech. 2016, 9, (7), 2909-2925.

7. Gueneron, M.; Erickson, M. H.; VanderSchelden, G. S.; Jobson, B. T., PTR-MS fragmentation patterns of gasoline hydrocarbons. Int. J. Mass Spectrom. 2015, 379, 97-109.

8. Yuan, B.; Warneke, C.; Shao, M.; de Gouw, J. A., Interpretation of volatile organic compound measurements by proton-transfer-reaction mass spectrometry over the deepwater horizon oil spill. Int. J. Mass Spectrom. 2014, 358, 43-48.

9. Verma, D. K.; Tombe, K. d., Benzene in Gasoline and Crude Oil: Occupational and Environmental Implications. AIHA Journal 2002, 63, (2), 225-230.

10. de Araujo, P. L. B.; Mansoori, G. A.; de Araujo, E. S., Diamondoids: occurrence in fossil fuels, applications in petroleum exploration and fouling in petroleum production. A review paper. International Journal of Oil, Gas and Coal Technology 2012, 5, (4), 316-367.

11. Ahad, J. M. E.; Pakdel, H.; Gammon, P. R.; Siddique, T.; Kuznetsova, A.; Savard, M. M., Evaluating in situ biodegradation of 13C-labelled naphthenic acids in groundwater near oil sands tailings ponds. Sci. Total Environ. 2018, 643, 392-399.

12. Paulssen, J. M.; Gieg, L. M., Biodegradation of 1-adamantanecarboxylic acid by algalbacterial microbial communities derived from oil sands tailings ponds. Algal Research 2019, 41, 101528.

13. Rowland, S. J.; Scarlett, A. G.; Jones, D.; West, C. E.; Frank, R. A., Diamonds in the Rough: Identification of Individual Naphthenic Acids in Oil Sands Process Water. Environ. Sci. Technol. 2011, 45, (7), 3154-3159.

14. Grice, K.; Alexander, R.; Kagi, R. I., Diamondoid hydrocarbon ratios as indicators of biodegradation in Australian crude oils. Org. Geochem. 2000, 31, (1), 67-73. 
15. Wang, Z.; Yang, C.; Hollebone, B.; Fingas, M., Forensic Fingerprinting of Diamondoids for Correlation and Differentiation of Spilled Oil and Petroleum Products. Environ. Sci. Technol. 2006, 40, (18), 5636-5646.

16. You, Y.; Moussa, S. G.; Zhang, L.; Fu, L.; Beck, J.; Staebler, R. M., Quantifying fugitive gas emissions from an oil sands tailings pond with open-path Fourier transform infrared measurements. Atmos. Meas. Tech. 2021, 14, 945-959.

17. Watson, J. G.; Chow, J. C.; Fujita, E. M., Review of volatile organic compound source apportionment by chemical mass balance. Atmos. Environ. 2001, 35, (9), 1567-1584.

18. Wren, S. N.; Mihele, C. M.; Lu, G.; Jiang, Z.; Wen, D.; Hayden, K.; Mittermeier, R. L.; Staebler, R. M.; Cober, S. G.; Brook, J. R., Improving insights on air pollutant mixtures and their origins by enhancing local monitoring in an area of intensive resource development. Environ. Sci. Technol. 2020, 54, (23), 14936-14945.

19. Li, S.-M.; Leithead, A.; Moussa, S. G.; Liggio, J.; Moran, M. D.; Wang, D.; Hayden, K.; Darlington, A.; Gordon, M.; Staebler, R.; Makar, P. A.; Stroud, C. A.; McLaren, R.; Liu, P. S. K.; O’Brien, J.; Mittermeier, R. L.; Zhang, J.; Marson, G.; Cober, S. G.; Wolde, M.; Wentzell, J. J. B., Differences between measured and reported volatile organic compound emissions from oil sands facilities in Alberta, Canada. Proc. Natl. Acad. Sci. 2017, 114, (19), E3756.

20. (EPA), E. P. A.

https://cfpub.epa.gov/speciate/ehpa_speciate_browse_details.cfm?ptype=G\&pnumber=8503. 21. Finlayson-Pitts, B. J.; Pitts Jr., J. N., Chemistry of the Upper and Lower Atmosphere: Theory, Experiments, and Applications. Academic Press: San Diego, 2000.

22. Krige, D. G., Two-dimensional weighted average trend surfaces for ore-evaluation. Journal of the South African Institute of Mining and Metallurgy 1966, 66, 13 - 38.

23. Luo, W.; Taylor, M. C.; Parker, S. R., A comparison of spatial interpolation methods to estimate continuous wind speed surfaces using irregularly distributed data from England and Wales. Int. J. Climatol. 2008, 28, (7), 947-959. 